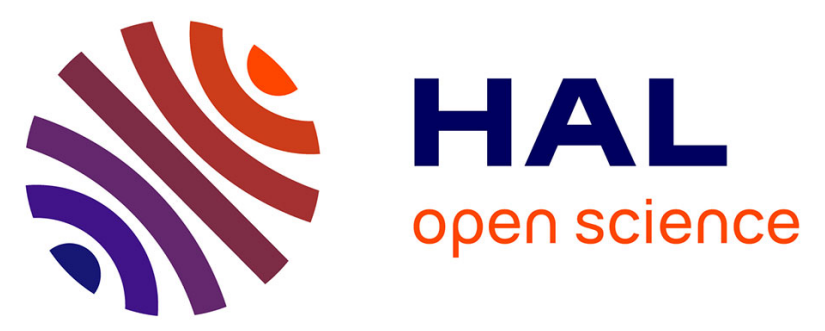

\title{
Holocene history of Lac des Lauzons (2180 m a.s.1.), reconstructed from multiproxy analyses of Coleoptera, plant macroremains and pollen (Hautes-Alpes, France)
}

Philippe Ponel, Mona Court-Picon, Monika Badura, Frédéric Guiter, Jacques-Louis de Beaulieu, Valérie Andrieu-Ponel, Morteza Djamali, Michelle Leydet, Emmanuel Gandouin, Alexandre Buttler

\section{To cite this version:}

Philippe Ponel, Mona Court-Picon, Monika Badura, Frédéric Guiter, Jacques-Louis de Beaulieu, et al. Holocene history of Lac des Lauzons (2180 m a.s.l.), reconstructed from multiproxy analyses of Coleoptera, plant macroremains and pollen (Hautes-Alpes, France). The Holocene, 2010, 21 (4), pp.565-582. 10.1177/0959683610385725 . hal-01968828v1

\section{HAL Id: hal-01968828}

\section{https://hal-amu.archives-ouvertes.fr/hal-01968828v1}

Submitted on 3 Jan 2019 (v1), last revised 8 Jan 2019 (v2)

HAL is a multi-disciplinary open access archive for the deposit and dissemination of scientific research documents, whether they are published or not. The documents may come from teaching and research institutions in France or abroad, or from public or private research centers.
L'archive ouverte pluridisciplinaire $\mathbf{H A L}$, est destinée au dépôt et à la diffusion de documents scientifiques de niveau recherche, publiés ou non, émanant des établissements d'enseignement et de recherche français ou étrangers, des laboratoires publics ou privés. 


\author{
Philippe Ponel,' Mona Court-Picon, ${ }^{1,2,3}$ Monika Badura, ${ }^{4}$ \\ Frédéric Guiter,' Jacques-Louis de Beaulieu,' \\ Valérie Andrieu-Ponel,' Morteza Djamali,' Michèle Leydet,' \\ Emmanuel Gandouin' and Alexandre Buttler ${ }^{3,5,6}$
}

\begin{abstract}
A $1.70 \mathrm{~m}$ core extracted from the Lac des Lauzons, Haut Champsaur, French Alps, at $2180 \mathrm{~m}$ altitude, provided a detailed Holocene record of beetles, pollen and plant macrofossils, enabling the reconstruction of local palaeoenvironmental changes during the last 10000 years. After an early phase of colonization by plants and insects, corresponding to the Lateglacial interstadial, a long phase of relative stability of the ecosystems (at least in the vicinity of the lake) is recorded. Strikingly, there is no evidence from beetle and plant macrofossils that the treeline reached the altitude of Lauzons during the Holocene climate optimum, although this period is characterized by major forest expansion in many high-altitude sites in the southern French Alps. The uppermost part of the record is blurred by the infilling of the lake, progressively turning into a peat bog. This sequence also provides an opportunity to compare the records of coprophilous fungal spores and coprophilous beetles and to improve the interpretation of these proxies in terms of their significance as proxies for pastoralism.
\end{abstract}

\title{
Keywords
}

climate, fossil Coleoptera, French Alps, Holocene, human action, plant macro-remains, pollen, treeline

\section{Introduction}

Reconstructing high-altitude palaeoenvironments from fossil biological material preserved in lakes and peat bogs is problematic. The complex orography and peculiar climatic conditions that prevail in mountainous regions (strong anabatic and catabatic winds, heavy rain and snowfalls, water streaming, erosion, etc.), play an important role in transportation and deposition of various macro- and microremains of vegetal or animal origin, and in the formation of fossil assemblages. The complex taphonomic history that results from the combined action of many factors are difficult to interpret since a significant part of the assemblages is often build up with allochthonous elements corresponding to long-distance transportation. Such phenomena primarily affect the smaller and lighter wind-blown elements, such as pollen grains, especially those of Pinus and other conifers (Andrieu et al., 1997; de Beaulieu, 1977; Brugiapaglia et al., 1998; Court-Picon, 2007; Ortu, 2002), but also, to a lesser extent, plant macroremains (leaves, seeds, samarae, etc.). Even dead or living insects and insect fragments, can be found in the high atmosphere levels (Berland, 1935). In mountains, the upward passive transportation of insects by winds and its implications in the interpretation of high-altitude fossil insect assemblages has been addressed by Lumaret and Stiernet (1990), Ponel et al. $(1995,1999)$ and Ponel and Richoux (1997). However, as a rule, the knowledge concerning the modern 'rain' of insects (and plant macroremains) is still in infancy (Smith et al., 2010), contrary to that of pollen (Andrade Olalla et al., 1994; Caseldine and Pardoe, 1994; CourtPicon et al., 2005, 2006; Frits et al., 1994; Ruffaldi, 1994).

The aim of this paper is to present the results of an attempt to overcome such difficulties using a multiproxy approach. The main objectives are (1) to reconstruct the Holocene palaeoenvironmental changes at a high-altitude alpine site from fossil Coleopteran assemblages, following an approach independent of other proxies such as pollen and plant macroremains, (2) to compare results

\footnotetext{
'Université Paul Cézanne Aix-Marseille III, France

${ }^{2}$ Ghent University, Belgium

${ }^{3}$ Université de Franche-Comté, France

${ }^{4}$ University of Gdańsk, Poland

${ }^{5}$ École Polytechnique Fédérale de Lausanne (EPFL), Switzerland

${ }^{6}$ Swiss Federal Research Institute (WSL), Switzerland
}

Received 19 March 2010; revised manuscript accepted 2 September 2010

Corresponding author:

Philippe Ponel, IMEP CNRS UMR 6116, Université Paul Cézanne

Aix-Marseille III, Europôle méditerranéen de l'Arbois, bâtiment Villemin, BP 80, F- 13545 Aix-en-Provence Cedex 04, France

Email: philippe.ponel@univ-cezanne.fr 


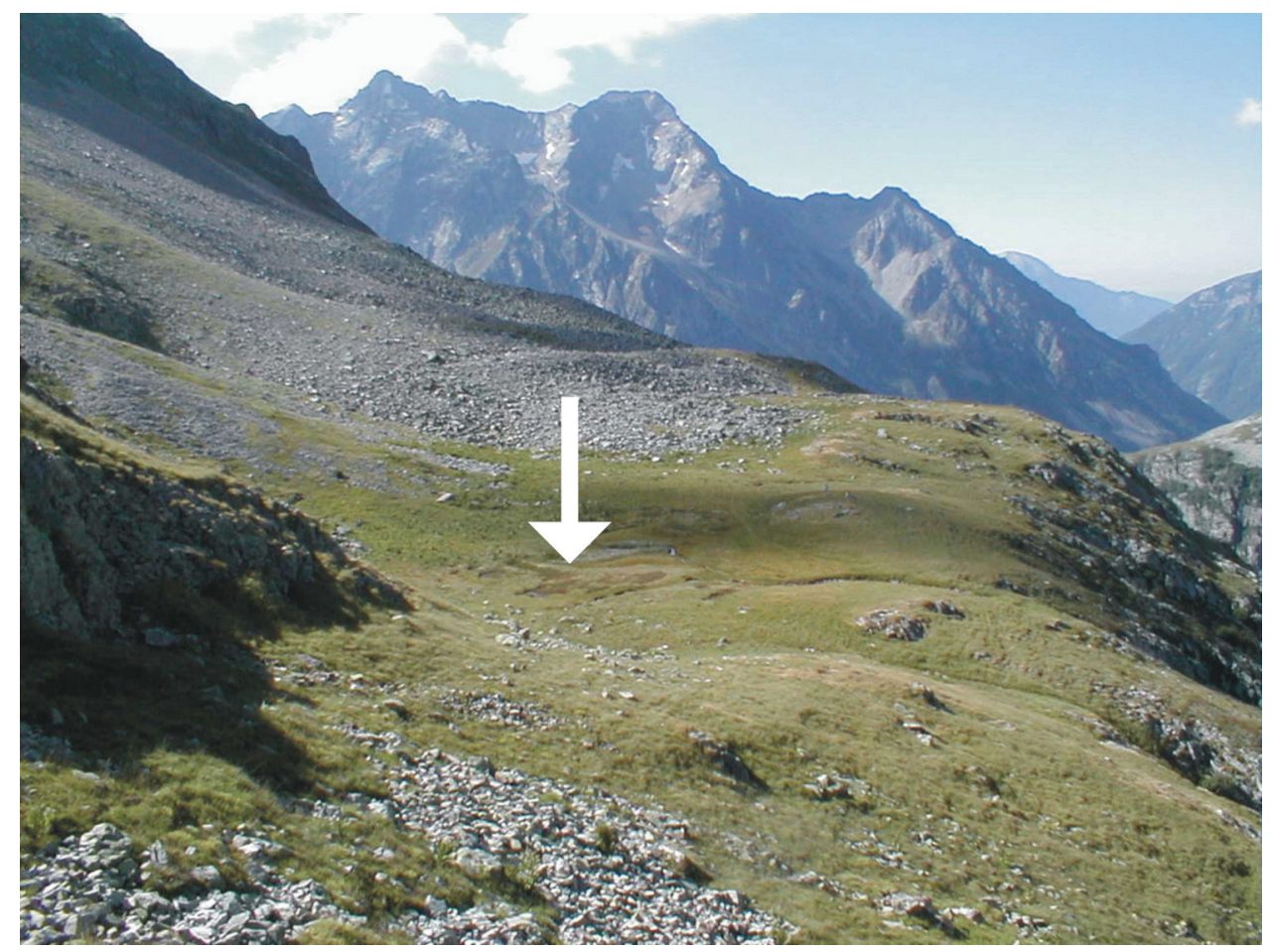

Figure I. Lac des Lauzons. The arrow indicates the coring site

of this study with those drawn from fossil pollen and plant macroremain analyses performed on the same sedimentary profile, (3) to compare these new data with results obtained from other Holocene sequences from the Alps (both palaeobotanical and palaeoentomological) (Ponel, 1997; Ponel et al., 1992, 2001a, b), (4) to evaluate the respective roles of humans and climate in controlling the position of the forest limit. The site of Lac des Lauzons provides an opportunity to investigate such issues since it is located well above the present-day upper forest limit (approximately $400 \mathrm{~m}$ above), at an altitudinal interval which seems potentially favourable for the establishment of a forest cover (Talon et al., 1998). Moreover, the Lac des Lauzons is located close to an archaeological settlement already thoroughly investigated (Palet Martinez et al., 2003), suggesting that human presence and activities were strong especially during the Bronze and Middle Ages; evidence for ancient peat exploitation is still visible (Court-Picon, 2007).

This paper is focused on Coleoptera, since coleopteran fossils may be considered as one of the most sensitive palaeoecological and palaeoclimatical indicators (Coope, 1998). This is a speciesrich group with about 10000 species in France that are valuable indicators of ecological niche. Coleopteran fossils can very often be identified to the species level and thus are potentially able to provide a wealth of palaeoenvironmental information inferred from the available literature on the ecology of modern species. Recent studies have also demonstrated that they are very abundant in high altitude Holocene lacustrine sediments and are able to provide original and independent data concerning climate, human activities and fluctuations of treeline level (Gaillard and Lemdahl, 1994; Lemdahl, 2000; Ponel, 1997; Ponel et al., 1992, 1999, 2001a, b).

\section{The study area}

The small peat bog of Lac des Lauzons $\left(0.3\right.$ ha, $44^{\circ} 47^{\prime} 01^{\prime \prime} \mathrm{N}$, $6^{\circ} 17^{\prime} 19^{\prime \prime} \mathrm{E}, 2180 \mathrm{~m}$ a.s.l.) is located to the north of
Champoléon in the Haut-Champsaur on a shelf of about 1 ha, at the margin of a steep rocky slope facing west-southwest in the Isola valley (Figures 1 and 2). The 'vallon d'Isola' is a steep-sided glacial valley, with abrupt slopes interrupted by narrow shelves. The Lac des Lauzons site is overlooked by Puy des Auberts $(2718 \mathrm{~m})$ to the southeast, it is hemmed in by a frontal moraine deposited probably during the Lateglacial. Thus it is a moraine-dammed lake in its final phase of infilling. The peat bog itself is established on altered lenticular banded gneiss (Debelmas, 1982). The site is today under the influence of a very harsh climate (low temperatures, heavy rain- and snowfalls) because of high altitude and proximity to glaciers. The climate of the Haut-Champsaur area is cool and wet with a period of snow cover lasting more than 4 months per year at elevations above $1800 \mathrm{~m}$. The mean annual precipitation ranges from 1500 to $2000 \mathrm{~mm}$ and the mean annual temperatures from $4^{\circ}$ to $6^{\circ} \mathrm{C}$ (Météo-France). The valley bottom of the 'vallon d'Isola' is occupied by a forest dominated by Betula pendula and Fraxinus excelsior; other tree taxa include Acer, Quercus, and Corylus avellana (Gobert et al., 1966). From $1530 \mathrm{~m}$ a.s.1. upward, broadleaved trees become scarce; Betula pendula is progressively associated with Larix decidua, dominant above $1700 \mathrm{~m}$ a.s.l. Above $1800 \mathrm{~m}$ a.s.l., the landscape changes to Festuca acuminata grasslands and Juniperus moorlands. Alnus alnobetula is restricted to narrow thalwegs. Above $1900 \mathrm{~m}$ a.s.1., the dominant associations are Seslerietum coerulae, Alnetum viride and Juniperetum nanae, with patches of Vaccinium and Rhododendron. Larix decidua is still present in the form of isolated specimens. Beyond $2130 \mathrm{~m}$ a.s.1., the vegetation of screes and moraines is dominated by acidophilous grasslands with Festuca violacea. The berm that holds the peat bog is located just above the treeline. The central part of the peat bog, almost entirely infilled, is occupied by Carex echinata, Veratrum album subsp. lobelianum and Juncus trifidus (Court-Picon, 2007). 


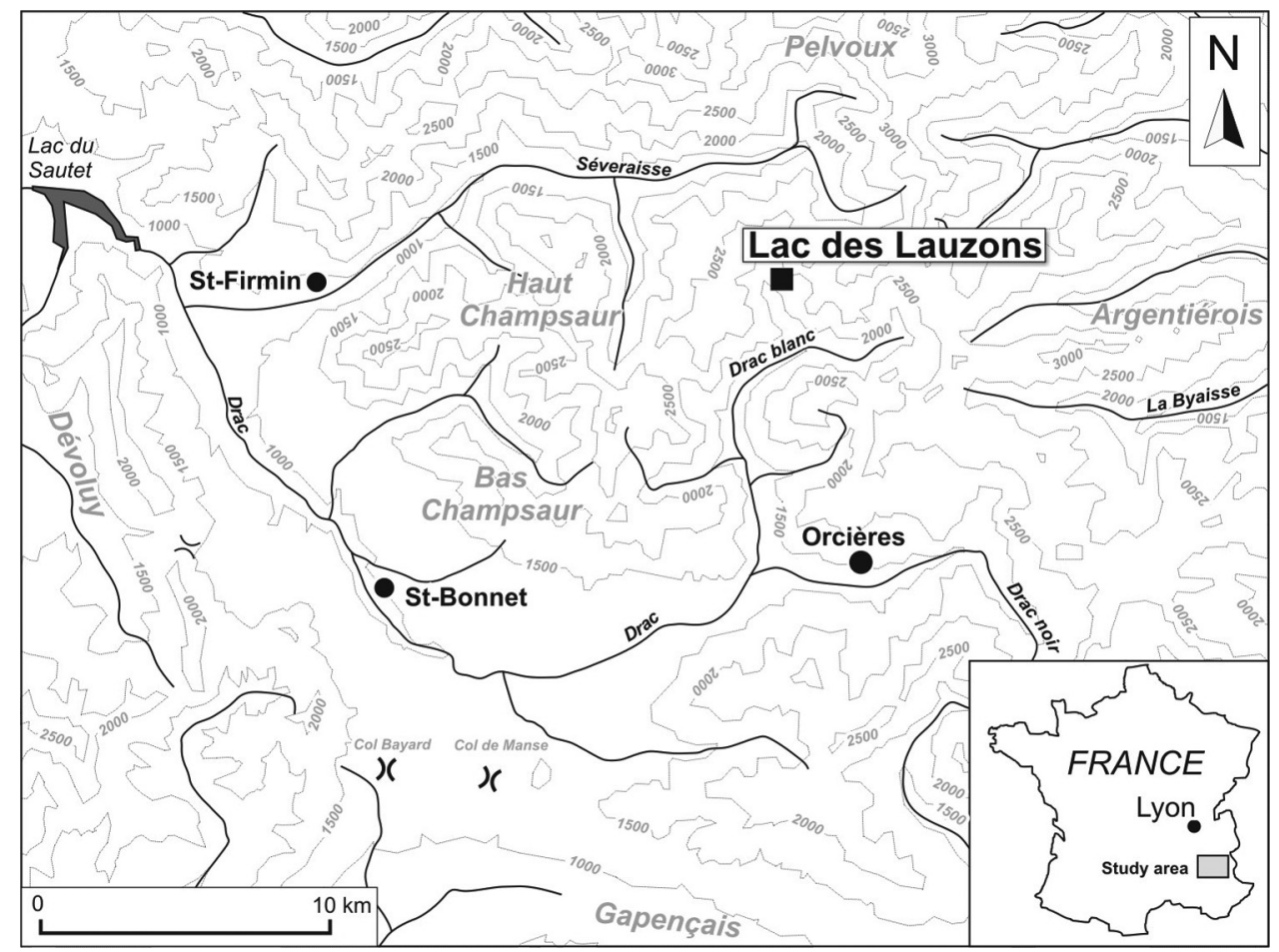

Figure 2. Location of the Lac des Lauzons peat bog in the Champsaur valley, southern French Alps (2180 m a.s.l., exposure S-SW)

\section{Material and methods}

\section{Coring, sampling, lithology}

Three sediment sequences located $50 \mathrm{~cm}$ apart were extracted with a Russian corer $(\varnothing 8 \mathrm{~cm})$ from the central part of the peat bog. The rocky bottom was reached at $1.70 \mathrm{~m}$ depth. One of the three cores was sampled for pollen analysis and radiocarbon dates. In order to get enough sediment the three sequences were then aggregated together and cut into 61 samples for plant and insect macrofossil analyses (Figure 3).

Coleopteran data. On average each sample was about $3 \mathrm{~cm}$ thick and $60 \mathrm{~cm}^{3}$ in volume. The 61 insect samples were numbered from 0 to 60 spanning continuously the entire $1.70 \mathrm{~m}$ of sedimentary profile, from the surface to the rocky bottom. The fossils were extracted using the method recommended by Coope (1986); wet sieving over a $300 \mu \mathrm{m}$ sieve, paraffin flotation of the residue, sorting under a binocular microscope. The insect remains were eventually preserved in alcohol or glued on pieces of cardboard. Identifications were made by direct comparison with specimens from a modern reference collection. Unless otherwise stated, the ecological and climatic interpretation of the fossil coleopteran assemblages is derived mainly from modern literature such as Balachowsky (1949), Coulon et al. (2000), Español Coll (1992), Hansen (1987), Hoffmann (1954, 1958), Holmen (1987), Jeannel (1941, 1942), Koch (1989a, b, 1992), Lindroth (1985, 1986, 1992), Nilsson and Holmen (1995), Pfeffer (1995), Vienna (1980), Zanetti (1987). Out of the 61 subsamples, 59 proved to be fossiliferous (sample 58 and 60 at the bottom of the sequence are totally devoid of insect remains). A total of 162 taxa were identified, including 151 taxa of Coleoptera, of which 86 (57\%) were identified to species or species-group level. Other insect orders include Heteroptera, Hymenoptera (Formicidae), Diptera (Bibionidae), Trichoptera, Dermaptera, Megaloptera, represented by very low numbers of taxa and individuals (Table S1, published online as supplementary material). As a whole, the coleopteran assemblages are rich, with almost 16 taxa of Coleoptera per sample, and up to 43 taxa in a very rich sample $(n=45)$. However it is necessary to keep in mind that the volume of sediment analysed per sample is small; therefore the absence of certain taxa in the fossil record cannot be firmly interpreted as their absence in the past communities. Only coleopteran data are discussed in this paper. The Coleoptera are grouped into ecological categories according to their preferred habitat and presented on a synthetic histogram (Figure 4) drawn with $\mathrm{C}^{2}$ software (Juggins, 2003). This grouping is based on the literature but also mainly on the field experience of one of the authors (P. Ponel). Two ecologically significant species (Helophorus glacialis and Aphodius mixtus) are also presented on the same figure.

- Open ground/high altitude Coleoptera (example: Bembidion bipunctatum, Bembidion subgenus Testediolum $\mathrm{sp}$.).

- Forest margin Coleoptera (representative examples: Eusphalerum spp., Anthophagus spp., Malthodes spp., see Ponel et al., 2001a, b).

- Conifer and leaf tree Coleoptera (presented on two separate histograms).

- Forest Coleoptera: Insects living exclusively in forest environments, but not necessarily feeding on trees.

- Damp ground Coleoptera: Non-aquatic insects associated with wetland and marshes.

- Standing water Coleoptera: Taxa adapted to poorly oxygenated water.

- Coprophilous Coleoptera: Directly coprophagous, or predatory on coprophagous insects.

- Unclassified: In this category are lumped together eurytopic Coleoptera, those whose ecology is not sufficiently known, and Coleoptera identified to genus or higher taxonomic rank level, which do not allow to draw any precise or unequivocal ecological data. 


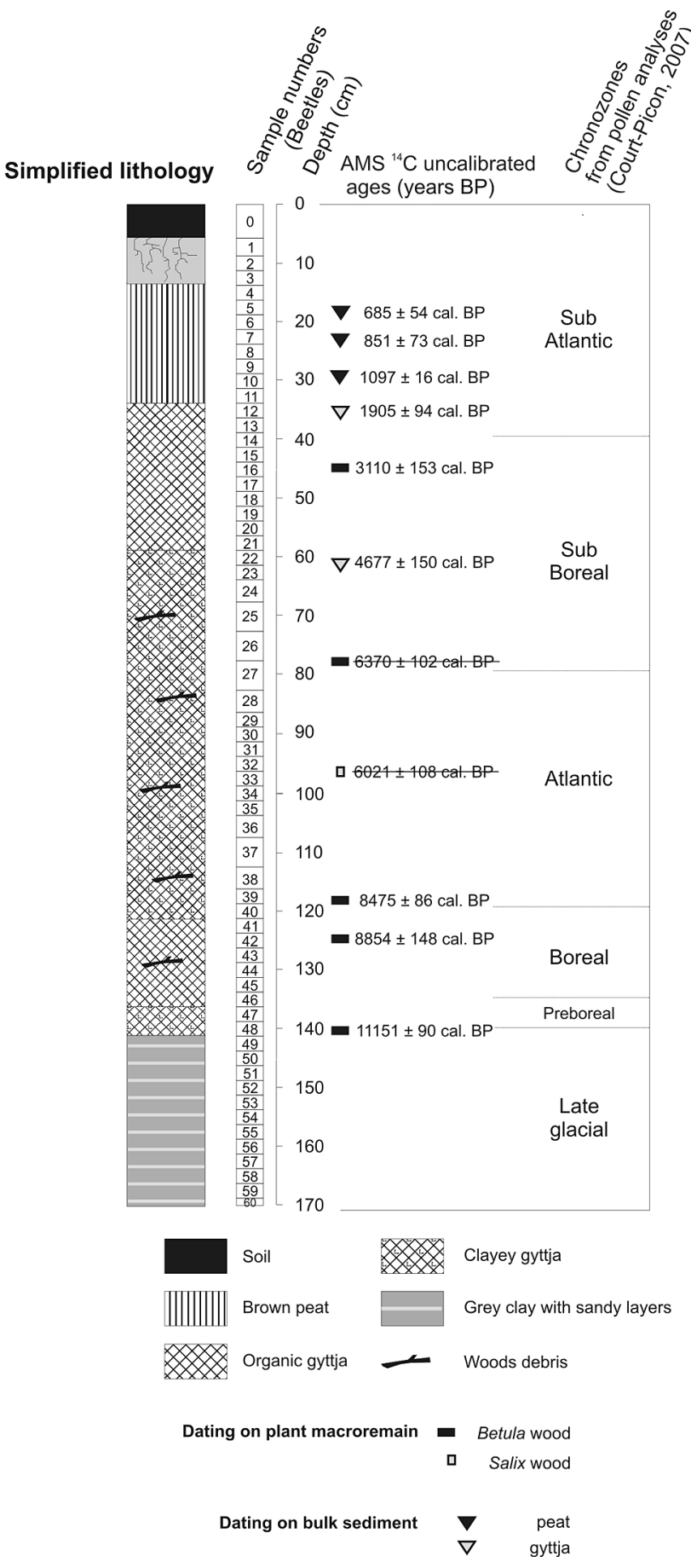

Figure 3. Lithology, depths, beetle sample numbers, pollen chronozones and AMS ${ }^{14} \mathrm{C}$ datings from the Lac des Lauzons sequence

- Helophorus glacialis: This very stenotopic insect is widely used as a palaeoclimate indicator. Its biological cycle requires that cold wet mud at the margin of melting snow patches is available in spring and in summer (Angus, 1992).

- Aphodius mixtus: Contrary to most of the other members of the genus, Aphodius mixtus is not dependent on excrement. This is a stenotopic Coleoptera which feeds on rotten vegetal matter during the larval stages, especially in leaf-litter accumulated at the base of turf. It is restricted to high altitude grasslands in European mountains (Ponel et al., 1995).

The sequence is divided into six Beetle Assemblage Zones (BAZ) numbered from the bottom to the top BAZ1 to BAZ6 (Figure 4).
These zones are established on the basis of differences in the specific composition of beetle assemblages as a whole and not only on the fluctuations of some indicator species.

Pollen data. Sediment samples for pollen analysis were taken at $2.5 \mathrm{~cm}$ intervals. Pollen was extracted from peat and gyttja sediments according to the method described by Faegri and Iversen (1975). Clayey sediments from the basis of the profile (137 to $170 \mathrm{~cm})$ were treated with a heavy liquor $(d=2.00)$ according to Goeury and de Beaulieu (1979). The simplified pollen diagram (Figure 5 and Figure 6, Court-Picon, 2007, modified) was drawn with GPalWin (Goeury, 1988).

Plant macrofossil data. The volume of each plant macrofossil subsample was measured and were then soaked for several hours in a $10 \% \mathrm{KOH}$ solution. Wet sieving was done with three sieves with $0.2,0.5$ and $2.0 \mathrm{~mm}$ meshes. Particular fractions of plant were selected, determined and counted under stereoscopic microscope. All seeds, fruits, buds and bud scales were picked from each of the sample. A mixture of alcohol, glycerine, distilled water and thymol was used for the preservation of fossils. The results of plant macrofossil analysis are presented on Figure 5 and Figure 7.

Radiocarbon dates. Eleven AMS radiocarbon datings were performed on bulk sediment and plant macro-remains (Laboratory of Isotope Geochemistry, Tucson, Arizona) (Table S1 online, Figure 4). The ages indicated on the figures are calibrated. The interpolated age-depth model (Figure 8) was created using the package CLAM (Blaauw, 2010) in the software R (R Development Core Team, 2010). The dates $6370 \pm 102 \mathrm{cal}$. BP and $6021 \pm 108$ cal. BP are inversed and are excluded from the interpolated line because of the uncertainty in the simultaneity of their age with the encompassing sediment (transported old wood).

\section{Palaeoecological records}

\section{Changes in beetle assemblages}

$B A Z I$, a pioneer insect fauna in a rocky desert (samples 49 to 60 ; I4I.25-I $70.00 \mathrm{~cm}$ ). The first phase of the insect succession (BAZ1) corresponds to an episode of colonization by a pioneering beetle fauna, early after the retreat of the ice cover at the onset of the Holocene. The only recorded aquatic Coleoptera is Agabus bipustulatus, a very euryoecious aquatic species able to colonize any type of water body, from warm lowland to cold mountainous areas. It was certainly the only inhabitant of the lake itself at that time, which is not surprising since (1) this highly adaptable water beetle is able to settle even in pure shallow water of high-altitude lakes, in a predominantly rocky environment (Nilsson and Holmen, 1995), and (2) according to Jackson (1973), A. bipustulatus is an excellent flyer, a good candidate to the colonization of recently deglaciated areas. Specimens from high altitude (Alps) or high latitude (Northern Scandinavia) have been referred to as $A$. solieri, however, recent taxonomic results show that these variations are clinal (Drotz, 1997; Nilsson and Holmen, 1995) and therefore no attempt to distinguish A. bipustulatus and A. solieri is made here. The first isolated occurrences of Aphodius mixtus (Figure 4) are certainly related to the availability of alpine grasslands at short distance of the lake, probably below the site, and it is likely that these specimens were carried on the wing into water by upward winds (Lumaret et al., 1996; Ponel et al., 1995). The absence of Helophorus glacialis and 


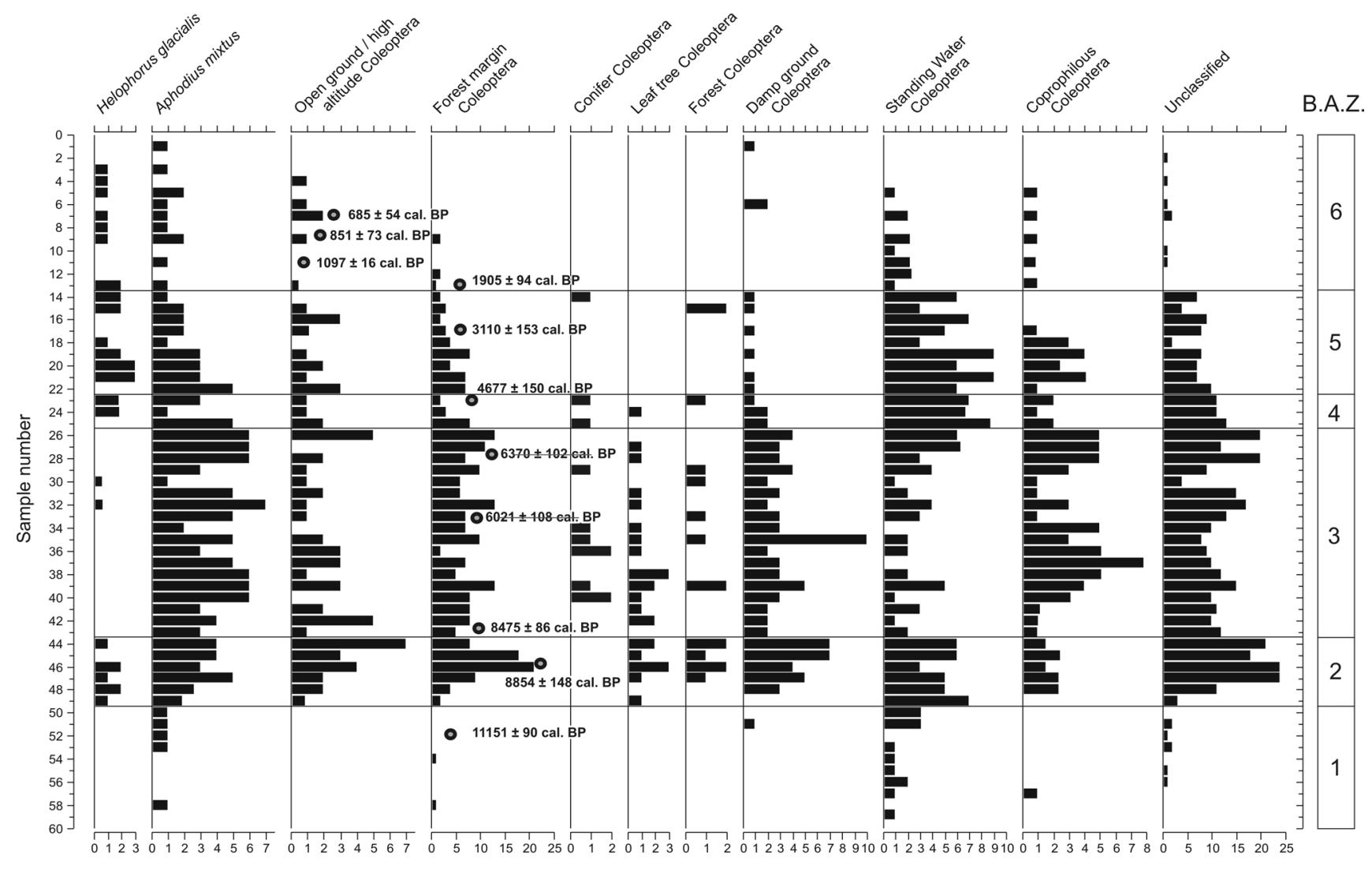

Specimens per sample

Figure 4. Histogram of ecological groups and selected Coleoptera species from Lac des Lauzons. BAZ, beetle assemblage zones

other open-ground or high-altitude Coleoptera, such as Bembidion bipunctatum, is surprising. The substratum, which was essentially rocky during these early stages of maturation, probably did not allow the development of this category of beetles (whose biological cycle needs some soil to be achieved). The palaeoenvironment at that time was certainly comparable to a rocky desert surrounding a proglacial lake inhabited by a very restricted pioneer insect fauna; no flora was present with the probable exception of cold adapted diatoms and other algae.

$B A Z 2$, rise of most of ecological groups (samples 43 to 48; $126.25-14 I .25 \mathrm{~cm}$ ). The next beetle assemblage zone (BAZ2) shows a marked rise in taxonomic diversity and a complete change in the composition of insect assemblages. Nearly all the ecological groups appear simultaneously in considerable number, with the exception of conifer-dependent Coleoptera. The first appearance of forest Coleoptera and leaf-tree Coleoptera are also recorded in this zone. From a palaeoclimatic and palaeoenvironmental point of view, the first occurrence of Helophorus glacialis is important. This boreomontane species lives at the edges of melting snow patches. It was already present at higher altitudes and descended at the lake Lauzons altitude when its temperature threshold was crossed. Average summer temperatures indicated by Helophorus glacialis are lower than $10^{\circ} \mathrm{C}$, close to the growth limit of the most tolerant trees (Ponel et al., 1992). This cold-adapted taxa certainly of local origin suggests that no true forest cover was present at that time. Several characteristic open-ground/highaltitude taxa are also recorded: Olophrum alpinum is commonly found here, on damp ground in wet and cold depressions where snow patches persist until late summer ('combes à neige'); Carabus depressus is mainly restricted to alpine grasslands up to $2500 \mathrm{~m}$ (Coulon et al., 2000). Selatosomus aeneus is a click-beetle also associated with high-altitude grasslands. The histogram of forest margin Coleoptera presents its maximum in this zone (Figure 4), suggesting that the treeline was located not very far below the site, but was composed of bushes or dwarf trees because of the rarity of Coleoptera which are dependent on mature forest. Forest margin Coleoptera include Eusphalerum spp., Anthophagus spp. and Malthodes spp., which are abundant along with Podabrus alpinus, Cantharis tristis, C. pagana, Cratosilis denticollis. Adoxus obscurus, a leaf beetle associated with Epilobium, is found repeatedly in this unit and suggests that 'willow herbs' were a major component of the flora at that time. Several specimens of Dascillus cervinus suggest that wet grasslands were present since this Coleoptera lives at the root of plants growing in damp areas covered with abundant herbaceous flora. The common scarabeid Serica brunnea suggests that heathlands, light pine woodlands or forest margins with sandy ground were located nearby. Deciduous tree Coleoptera and forest Coleoptera are also present in this unit but in low number of taxa and individuals, suggesting that large trees were probably not present on the site itself. This is the case for Grynobius planus, usually common in dead wood of old trees (often Fagus), and for the many specimens of Curculio, a genus containing one species associated with Corylus (hazel), the other ones associated with Quercus (oak). The only specimen of Xylodrepa quadripunctata recorded in this sequence is also identified in this unit. This Silphidae prefers Quercus forests, where it feeds upon various moth larvae such as Lasiocampa quercus. Most of these leaf tree Coleoptera fly readily, therefore, it is likely that the rare specimens recorded in the assemblages were carried from lowland forests into the site by upward winds. There is no doubt that Quercus and 


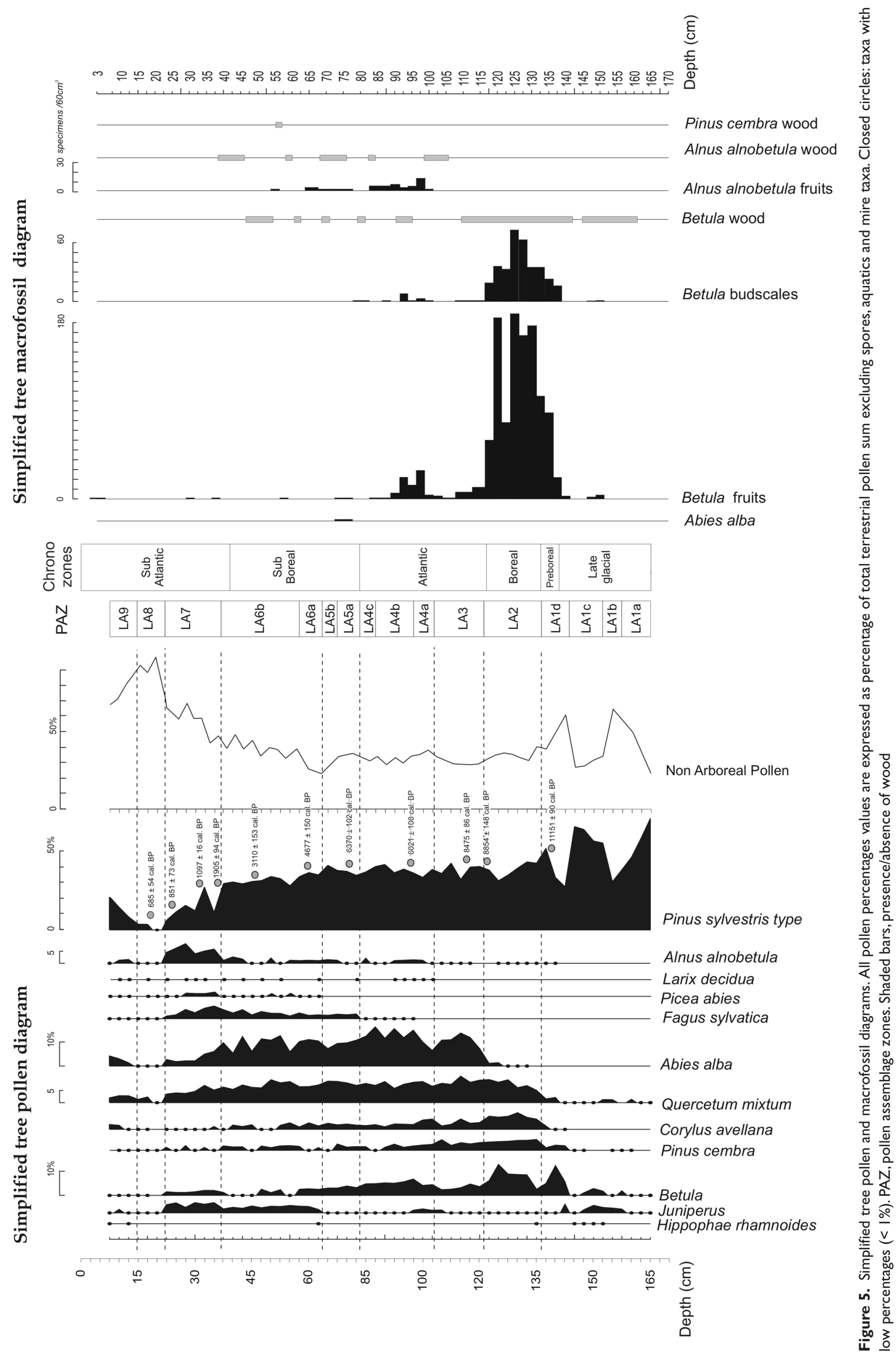




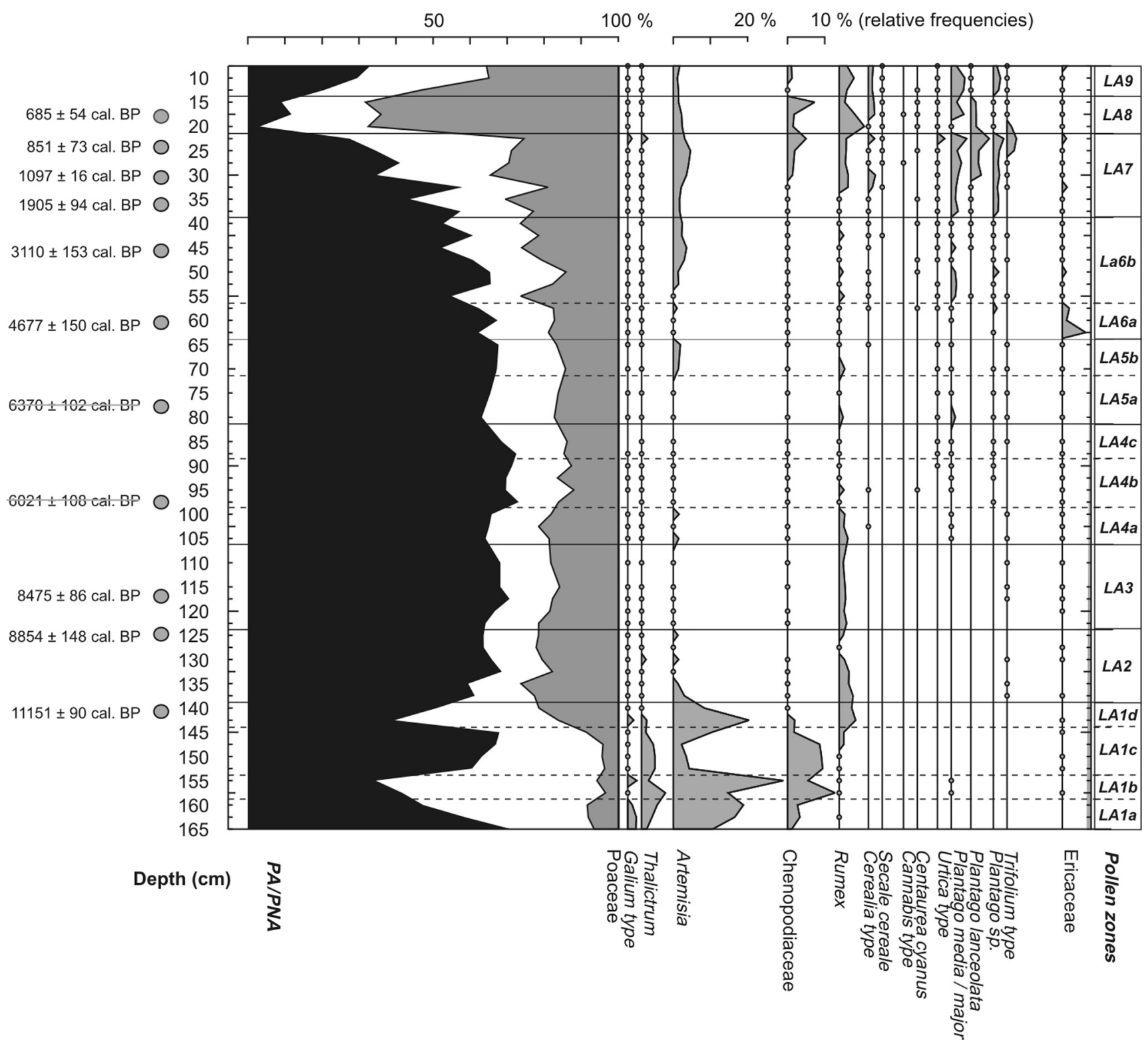

Figure 6. Simplified pollen diagram showing occurrences of plants associated with cultivation and pastoralism, and radiocarbon dates

Corylus grew at some distance, probably in the Isola valley. The only evidence for forest environment could occur in the form of two specimens of Cychrus attenuatus, often considered as a forest species (Coulon et al., 2000) since this large Carabidae species is wingless and therefore cannot be lifted and carried by winds from the low altitude forests. However, unpublished observations (Coulon, personal communication, 2006) suggest that in the region Cychrus attenuatus is able to live above the forest limit, in very open environments such as rocky alpine grasslands or grasslands with sparse bushy vegetation. The transition from BAZ1 to BAZ2 is marked by a considerable change in the water beetle fauna, reflecting a major change in the environmental and hydrological conditions. At the contact between these two faunal units, Hygrotus inaequalis occurs in two adjacent samples, suggesting that rich vegetation was then established in the lake. Later on, the water beetle assemblages are dominated by Hydroporus spp., Acilius sulcatus, Hydrobius fuscipes. Again, Acilius sulcatus is a species found in lakes and ponds with well-developed marginal vegetation (Nilsson and Holmen, 1995). Presence of the latter species along with Hygrotus inaequalis, suggests that the lake was fringed by abundant hygrophilous plants. Some gravely or sandy beaches were also certainly present, as indicated by Lesteva longoelytrata, but more peaty soils are revealed by Pterostichus diligens and Lathrobium terminatum. BAZ2 corresponds also to the expansion of a rich coprophilous and coprophagous beetle fauna, suggesting that the lake shores were frequented very soon by wild mammals: Geotrupes are large coprophagous dung beetles that need large masses of dung which are stored in underground reproductive galleries, whereas the smaller Onthophagus ovatus and Aphodius obscurus may be satisfied with dung provided by small mammals. Heptaulacus carinatus is present in almost every sample of BAZ2 (and throughout the sequence upward to BAZ4). According to Lumaret (1990), it is an alpine species preferring high-altitude dry grasslands (up to $2700 \mathrm{~m}$ ) where it feeds on varied dung. Today, H. carinatus is very common in the Alps.

The palaeoenvironment of the site during the deposition of BAZ2 shows a considerable change in comparison with the previous beetle zone: An abundant herbaceous vegetation is now growing on the site itself, which has evolved from a rocky depression to a marsh surrounded by boggy grounds and bare beaches, and small trees or bushes were certainly present nearby, perhaps in the form of waterside vegetation fringing the lake. The scarcity of 


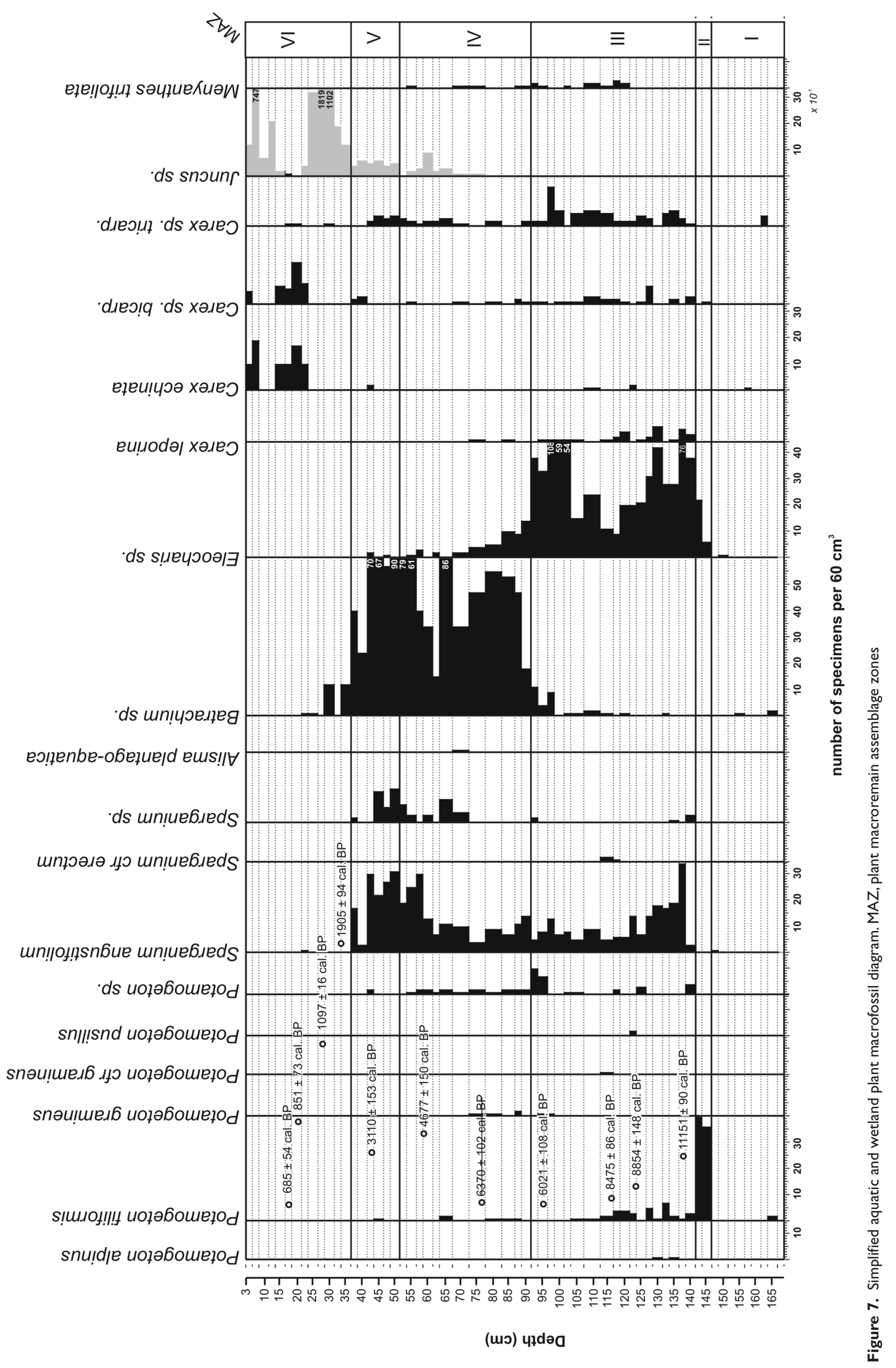




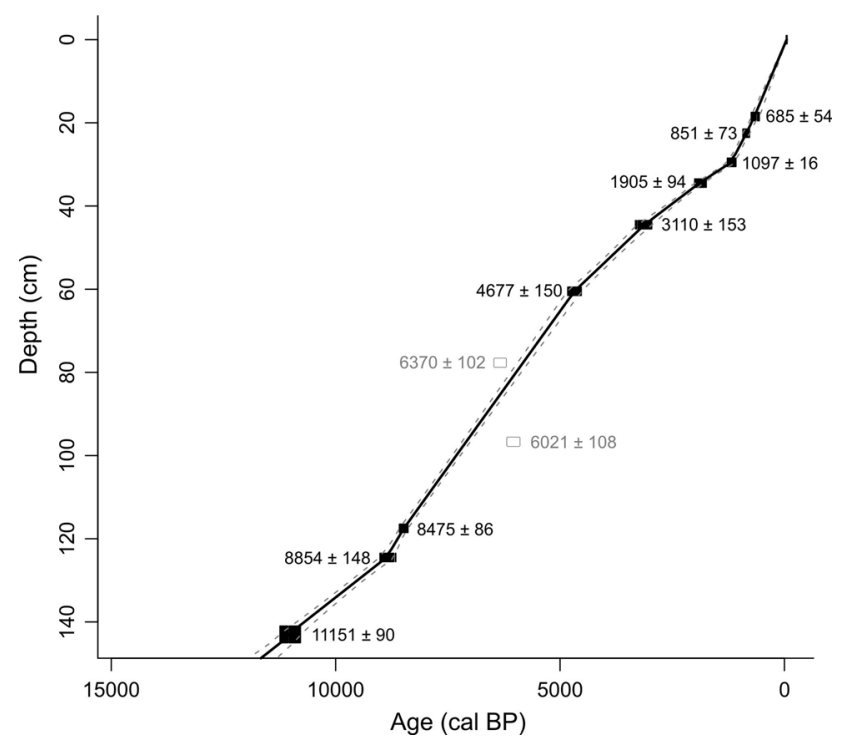

Figure 8. Age-depth model created using CLAM package developed by Blaauw (2010) for $R$ statistical software ( $R$ Development Core Team, 20I0). Two ages in grey were excluded from the interpolated line because of the uncertainty in the simultaneity of their age with the encompassing sediment

forest ground beetles and of phytophagous taxa associated with trees suggests that no real forest covered the slopes close to the Lauzons lake. On the contrary, vast tracts of grasslands dominated the area. However, the occurrence of isolated specimens of treedependent Coleoptera indicates that true deciduous forest occupied the valley below the site.

$B A Z 3$, drying out of the lake, rise of forest limit, mature forest down in the valley (samples 25 to 42; 67.50-126.25 cm). This zone is marked by three main events: The transitory disappearance of Helophorus glacialis (three specimens only are found in the upper part of BAZ3), the incoming of conifer-dependent Coleoptera, and a strong decrease in Coleoptera indicator of standing water conditions centred in the middle of this BAZ. The disappearance of Helophorus glacialis and the appearance of conifer-dependent Coleoptera suggest that a pronounced change in the environment takes place in this unit, but the very low number of specimens of the latter category (only 8 specimens in the 18 samples of faunal unit BAZ3) indicates that conifers were present in the form of isolated stands and/or individuals, or are located far away from the site. Moreover, open-ground/high-altitude Coleoptera are still well represented in this unit, with several very characteristic species such as Bembidion bipunctatum and Olophrum alpinum (which are almost as cold-adapted as Helophorus glacialis), Harpalus fuliginosus, Ctenicera cuprea. Like other species of the genus Licinus, the ground-beetle L. depressus is associated with open, dry and sunny environments, along with Notiophilus. The high-altitude ladybird species Semiadalia rufocincta and Chelonitis venusta are both endemic in the Alps, living in grasslands at about $2000 \mathrm{~m}$ altitude and above. Chelonitis venusta could well be associated with some aphid species parasiting Dryas octopetala since according to Caillol (1913) and Koch (1989b), this Coccinellid is frequently found in tufts of the Aven Mountain in rocky areas. The abundance of Aphodius mixtus remains a dominant feature of the assemblages since this Scarabaeidae is present in every sample of BAZ3, in significant numbers (up to 7 specimens in sample 31 see Figure 4). This detritivorous
Aphodius is present today at high altitude (up to $2900 \mathrm{~m}$ ) in the Alps, Massif Central and Pyrénées. It is commonly found in alpine grasslands with organic-rich wet soil. Adults appear in May and June, sometimes in huge numbers in favourable conditions (up to 20 individuals $/ \mathrm{m}^{2}$ in humid grassy depressions). They fly readily during sunny days, fall in hundreds at the surface of snow patches and die. Later, when snow melts, dead insects are carried by streams into depressions, bogs and lakes, and accumulate in sediments (Lumaret et al., 1996; Ponel et al., 1995).

Many previously unrecorded taxa belonging to the forest margin Coleoptera group appear in BAZ3, as for example Anthophagus spectabilis, Anthophagus alpinus, Anthophagus alpestris, and Dalopius marginatus. Several individuals of Deporaus betulae suggest that birch, alder or hazel were present nearby. Female specimens of $D$. betulae construct a leaf roll by rolling up a part of a leaf of such trees, and then lay an egg in it (Hoffmann, 1958). The attribution of Phyllopertha horticola and Hoplia argentea to the category of forest margin Coleoptera may be debated, however, from bibliographic data (Paulian, 1959; Paulian and Baraud, 1982) and from personal observations of the first author it appears that both species are neither open environment nor forest insects, but are rather more common in areas with bushy vegetation, or with dominance of young or small trees. An ecologically significant insect, Phloeostichus denticollis is recorded in sample 26 (near the top of BAZ3). This saproxylophagous beetle is a very rare corticolous species associated with mature forests, it is frequently found under loose bark of old trunks of Acer, occasionally of Fagus. Its modern distribution in France is restricted to the Alps and the Vosges Mountains (Rose and Callot, 2007; SainteClaire Deville, 1935-1938), and in southern and central parts of Central Europe (Koch, 1989b). In the Lauzons lake fossil record, such Coleoptera suggests that the forest, lower down in the valley, was not simply a young formation recently established but a mature forest with big old trees, dead wood and loose bark. The conifer-associated beetles include Toxotus cursor, Leptura dubia, and several bark-beetles (Hylastes ater, Pityogenes, Pityokteines vorontzowi) and weevils (Pissodes). Toxotus cursor and Leptura dubia are montane Cerambycidae able to live up to $2000 \mathrm{~m}$ or at the limit of the treeline, their larvae are recorded in various conifers: Pinus, Abies, Picea, maybe also Larix. Since none of them is exclusively dependent on one specific conifer species, it is not possible to deduce from these insects that any particular conifer species was present in the area. The leaf tree Coleoptera association is not markedly different from that found in BAZ2; Curculio spp. are still dominant, with a few other species associated with Quercus, Corylus and Fagus, such as Dasytes coeruleus that feed on beech. Trachys minutus is a common jewel-beetle preferring Salix and Corylus. The woodborer associated with old trees Grynobius planus already found in BAZ2 is still present in BAZ3.

There is a marked decrease in number of individuals of standing water beetle, since 32 individuals have been counted in the six samples of BAZ2 and 52 individuals in the 18 samples of BAZ3. In two of the assemblages ( 33 and 36), this category is even totally missing. Such change is clearly correlated with a drying up of the lake. There is no marked change in the faunal composition, still dominated by three taxa: Hydroporus spp., Agabus bipustulatus and Limnebius truncatellus. The large dytiscid Acilius sulcatus represented by several specimens in BAZ2 disappears in BZ3 and is also absent in the following beetle zones. Contrary to other small species, it inhabits small lakes and larger ponds (Nilsson and Holmen, 1995) and is certainly not adapted to live in small pools 
remaining on the site. The damp ground association remains almost unchanged by comparison with BAZ2, with the predominance of the same three species (Argutor diligens, Lesteva longoelytrata and Lathrobium terminatum), suggesting that the nature of the substratum did not differ much from that of BAZ2. In BAZ3, the coprophagous and coprophilous fauna is much more diverse than in beetle zone BAZ2: Coprophilous staphylinids (Oxytelus, Aleochara) are now abundant, Onthophagus cf. fracticornis is recorded regularly and is not found elsewhere; it suggests clearly that grazing animals (wild animals or cattle) were present. Heptaulacus carinatus is still identified in most of the samples. The histogram of dung-dependent Coleoptera is marked by a first peak centred at sample 38, and a second rise at the end of BAZ3 (Figure 4). The most striking feature in BAZ3 is the complete disappearance, at the top of the zone, of Cantharis tristis (last occurrence in sample 28), which was an important component of this unit and of BAZ2. Unfortunately, the precise biology of this species is not well understood, and such decline is difficult to explain. However, since it is acknowledged that Cantharis tristis is a floricolous species often found in blooming grasslands at or just above the treeline, this brings us to the question of whether the peak of coprophagous Coleoptera also recorded at the top of BAZ3 is a sign of an increased occupation of the site by domesticated (or wild) mammals, followed by increased browsing, leading to the destruction of the herbaceous layer and flowering plants.

In spite of some marked differences in the faunal composition, the local palaeoenvironment around the site of Lauzons itself was certainly not very different in BAZ3 in comparison with the underlying unit. Open environments still prevailed, as indicated by the overall dominance of many insects strictly associated with open grasslands but a conifer forest was probably established in the region, a few kilometres away from the lake. Concerning the temporary rarefaction of standing-water beetles, there is no doubt that the hydrological regime of the lake underwent a marked change, e.g., a drying out of the water body, but it is difficult to disentangle the respective role of local factors and large-scale climate changes.

BAZ4, climate cooling? (samples 22 to $24 ; 58.75-67.50 \mathrm{~cm}$ ). This short period corresponds to an indentation in the curve of many taxa or categories, such as Aphodius mixtus, forest margin, and coprophilous Coleoptera. The histogram of damp ground Coleoptera shows a marked decrease, with for example the final disappearance of Pterostichus diligens, once common in BAZ3. In BAZ4 is also recorded for the first time a monophagous weevil, Rhynchaenus fagi, exclusively associated with Fagus. This diminutive insect is sometimes overabundant today in Fagus forests; it digs small holes in the leaves of beech trees, both at adult and larval stages. Conifer-associated weevils are represented by Pissodes sp. and Ryncolus elongatus. It is difficult to interpret these few beetle assemblages in terms of climate but the occurrences of specimens of Helophorus glacialis suggest a cooling associated with increased snowfall.

$B A Z 5$, lowering of the treeline and progressive infilling of the lake (samples 13 to $21 ; 36.25-58.75 \mathrm{~cm}$ ). This unit (along with the previous one BAZ4) is marked by high numbers of standingwater Coleoptera. They are well represented throughout the whole unit BAZ5, although a decline is observed in the upper half. Regular occurrences and many individuals of Helophorus glacialis are also recorded, suggesting that more snow was available in summer, probably because the climate was more humid if not cooler than in the underlying unit. Almost all the other taxa and ecological categories (Aphodius mixtus, forestmargin, damp-ground and coprophilous Coleoptera) record losses. It is likely that such steady decline cannot be attributed to ecological changes only, but may well relate to some taphonomic processes or temporary acceleration of sedimentation rate. Leaf tree, conifer- and forest-dependent Coleoptera are much more sporadic than in BAZ3 + BAZ4, or even extinct. Tree-dependent species include the conifer-associated weevil Magdalis sp., and the forest leaf litter rove beetle Omalium rugatum. The group of forest margin Coleoptera is also regularly declining throughout BAZ5. Surprisingly, the forest margin species Cantharis pagana is present again in BAZ5 after a long absence, though the ecology of this species is not sufficiently known to explain these two separated sets of occurrence.

Aphodius mixtus shows a steady decline from the bottom to the top of BAZ5. This decline of a grassland species cannot be interpreted as a closing of the environment related to a rise of the treeline since other open-ground/high-altitude Coleoptera are still abundant, especially Bembidion bipunctatum which occurs in almost every sample of this unit, along with Bembidion (Testediolum) sp. (also a snow patch taxon), the terrestrial Helophorus schmidti and Pterostichus morio, all associated with alpine grasslands. The coccinellid Chelonitis venusta already recorded in BAZ3 is still present. The last specimen of the staphylinid Olophrum alpinum recorded in this sequence is found in sample 21. This is another species of beetle usually found near snow patches. Standing-water Coleoptera are particularly well represented in BAZ5, but it is interesting to note that there is stability in the taxonomic composition of the assemblages; by comparison with BAZ3 and BAZ4, no new species or taxa are recorded. The main components of the group are Hydroporus sp., the ubiquitous Agabus bipustulatus and Limnebius truncatellus (both are especially frequent in this zone). The taxonomic and ecological complexity of the genus Hydroporus (including almost 40 French species) did not allow us to identify the fossil fragments to the species level and therefore no really useful palaeoecological information may be inferred from this taxon. The number of specimens of damp-ground Coleoptera declines strongly and the final loss of several taxa is recorded.

Data drawn from the beetle zone BAZ5 obviously show that a very open environment prevailed throughout. The decline of all the arboreal categories of Coleoptera attests to a lowering of the treeline. It is unlikely this decrease may be explained in terms of poor preservation conditions since other categories such as water beetles are thriving. The inflation of the standing-water beetle category is difficult to explain from the Coleopteran record alone, but a wetter climate could be the cause of their recurrence in this zone. This problem will be discussed in the light of other indicators, such as pollen or plant macroremains.

BAZ6, the lake turns into a peat bog (samples 0 to $12 ; 0.00$ $36.25 \mathrm{~cm})$. The upper beetle zone BAZ6 corresponds to the simultaneous collapse of almost all ecological categories, especially in the samples from the top of the sequence. However, insect evidence suggest that no marked environmental change took place at the end of the sequence; some taphonomic factors associated with the progressive infilling of the lake and its evolution into a peat bog are probably involved in this final collapse. The last insects represented by significant numbers are Helophorus glacialis, Aphodius mixtus (and some other open-ground Coleoptera), and the aquatic Coleoptera. Conifer, 


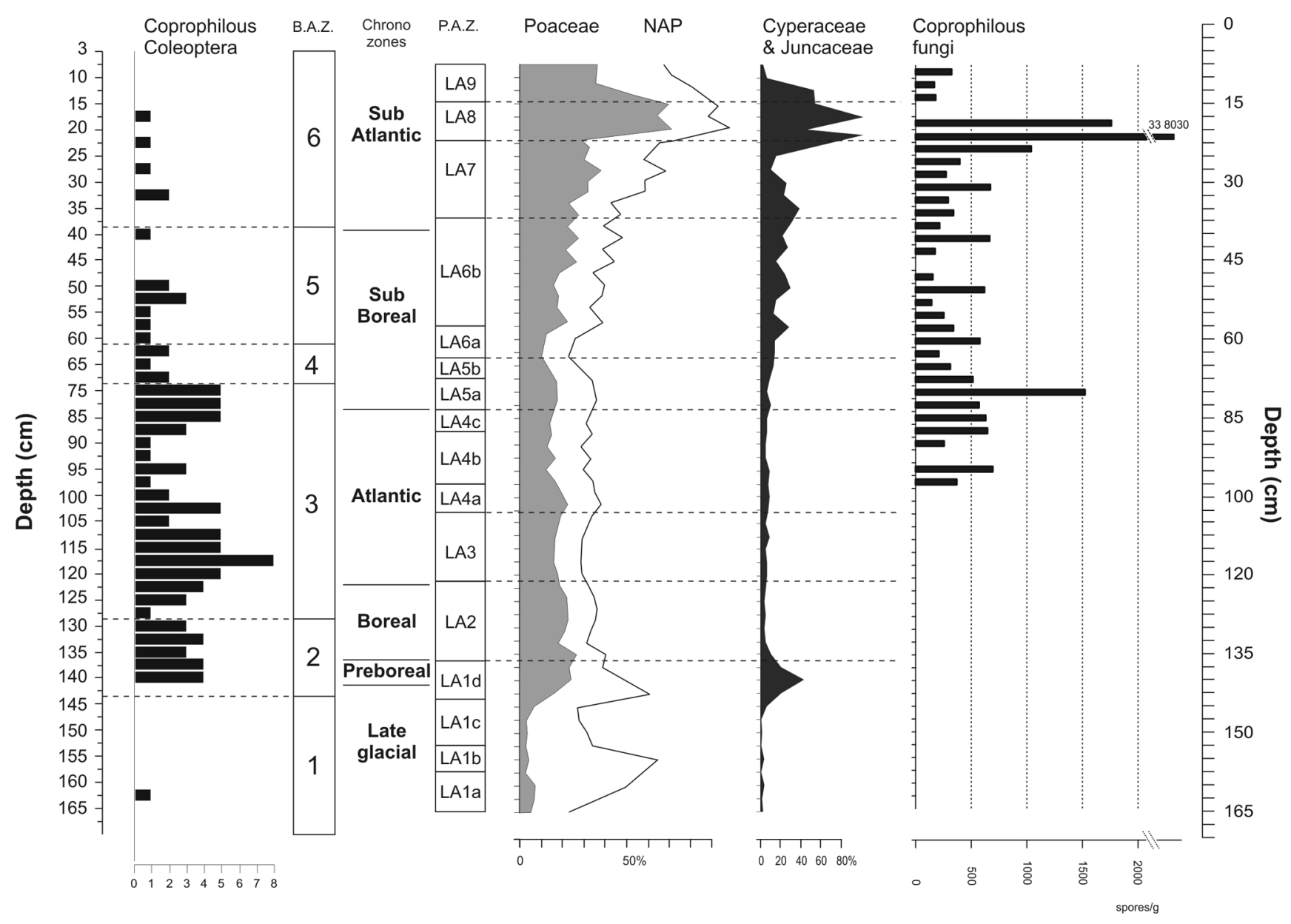

Figure 9. Selection of Coleoptera (coprophilous taxa), hygrophilous pollen taxa, and coprophilous fungal spores. BAZ, beetle assemblage zones; PAZ, pollen assemblage zones

leaf-tree and forest Coleoptera are totally extinct in BAZ6. Such impoverished assemblages do not enable us to establish a sound reconstruction of the landscape, but it is likely that completely open environments prevailed at that time.

\section{Vegetation changes}

Detailed pollen and plant macroremains from Court-Picon (2007) will be published elsewhere and only simplified diagrams are presented in this paper (Figures 5, 6 and 9). The pollen sequence can be divided into nine pollen assemblage zones (PAZ), which document the history of vegetation with a reliable time resolution.

Forest dynamics. Following the retreat of glaciers after the last glacial maximum, pioneer plants (mainly herbaceous taxa) typical of a cold and steppic environment spread over the shelf of Lac des Lauzons (PAZ LA1, 165-137.5 cm). Pollen from Quercetum mixtum can be attributed to long-distance transport. The absence of macroremains of Pinus cembra and Pinus sylvestris type suggests that upward transport from the valley is probably responsible for the presence of pine pollen in Lac des Lauzons; at that time the treeline was lower than $2000 \mathrm{~m}$ a.s.l. (Figure 5). Macroremains of Betula show its early local presence, but certainly few in number since the percentages of birch pollen are quite low during the Lateglacial period. During the LA1d zone, attributed to the Preboreal, Betula started to develop local shrub vegetation. Pinus cembra, Alnus alnobetula, Corylus avellana and trees from the Quercetum mixtum moved to higher altitudes, but did not reach the shelf of Lac des Lauzons, as shown by the absence of macroremains of these taxa. Among the herbaceous taxa, the Cyperaceae marked a peak (Figure 9), suggesting a rich lakeside vegetation colonisation and a change to mesotrophic water conditions. All these features point to an improvement of the environmental conditions (climate warming, soil development).

The Boreal (PAZ LA2, 137.5-122.5 cm) is marked by a moderate regional expansion of Corylus avellana and mixed oak forest taxa that developed at lower altitudes, in the Isola valley. Locally, the site is still rather open and occupied in some places by a birch open wood near the shores of the lake and on the fen zones, together with Juniperus on the shallowest and driest soils, and thickets of Alnus alnobetula which develops on the damp grounds, humid slopes and thalwegs. During this period, the highest amount of Betula macrofossils are recorded. These may indicate a locally dense belt of this tree. To the north of the Alps, in the Maurienne Massif, David and Barbero (1995) have shown that a Betula maximum, diachronic according to the altitude, corresponds to a pioneer expansion from lower altitude, which precede the arrival of the subalpine coniferous forests.

A rapid expansion of Abies, which marks regionally the beginning of the Atlantic, is reflected at Lauzons (PAZ LA3, 122.5$102.5 \mathrm{~cm}$ ). Abies was certainly present in the lowlands at $c .8800$ cal. BP as this is suggested by the increasing pollen curve of Abies (Figure 5). The increasing humidity recorded at $8200 \mathrm{cal}$. BP in Europe (Blunier et al., 1995) favoured large expansion of Abies. 
In the inner French Alps, fir found new areas for colonization, forming a new altitudinal belt, the montane coniferous forest. Later, competition between Pinus, Corylus avellana, but also Betula and Alnus alnobetula might have caused a slight but general decrease of Abies (Müller et al., 2006). Birches are still present in the vicinity of the lake, as shown by the large amount of macroremains found in this zone (Figure 5).

During the middle and later Atlantic (PAZ LA4, 102.5-85 cm) the first signs of human activities appear. They are expressed in the arboreal pollen record by a temporary decrease of the Abies percentages, suggesting a significant clearing of the fir forests at lower altitude by Neolithic populations. Such an event is regularly recorded in most of the pollen sequences from the Champsaur basin (Court-Picon, 2007), giving heliophilous trees (Larix, Juniperus, Betula, Alnus alnobetula) a chance to spread. But the occurrences of badly wind-transported non-arboreal taxa linked with human disturbances (Urtica, Plantago sp.) also suggest the local presence of Neolithic cattle (Figure 6).

The first occurrence of single pollen grains of Fagus in the diagram is dated approximately to $6100 \mathrm{BP}$ (PAZ LA4b, Figure 5 ); but the percentage curve becomes continuous at around 6000 cal. BP (PAZ LA5, 85-62.5 cm), underlying the progressive approach and expansion of Fagus in the vallon d'Isola during the early Sub-Boreal, while fir forests decrease.

As it is suggested by non arboreal pollen data (such as Rumex, Plantago sp.) represented in Figure 6, local human activities probably occurred during the middle Sub-Boreal (LA6a). Episodes of forest clearance during the Bronze and Iron Ages (in order to provide new areas for settlements, pastures and wood for construction and fuel) are recorded in the diagram (PAZ LA6b, 57.5-37.5 cm) with a lowering of AP/NAP curve together with increasing occurrences of anthropogenic flora. This period is contemporaneous with a Bronze Age settlement at less than $100 \mathrm{~m}$ from the Lauzons bog, as evidenced by Palet Martinez et al. (2003).

Human impact increased during the Sub-Atlantic (PAZ LA7, $37.5-22.5 \mathrm{~cm}$ ). During the Roman period the slopes surrounding the Lac des Lauzons were used as pasture for livestock, as shown by the rise of shrubs and NAP (pollen indicators of grazing and ruderal communities, such as Rumex, Plantago) (Figure 6), and by the increasing curve of coprophilous fungi (Figure 9). Deforestation led to the reduction of arboreal taxa such as Abies, Pinus, Corylus and taxa from Quercetum mixtum. Woody plant macroremains practically disappeared totally, pointing to local intensive grazing and lowering of the treeline. The rising anthropic pressure on the natural environment at lower altitudes is also recorded by the expansion of cereal (Figure 6). At the same time, the development of the lake into a peat mire took place. The change from fine detritic gyttja to peat, the decrease in aquatic taxa pollen, and the rapid colonisation of the fen margins by Poaceae and Cyperaceae/Juncaceae suggest a transition from limnic to telmatic environment.

Intensive clearings are documented from the Central Middle Ages (PAZ LA8, 22.5-15 cm) at every altitude in the region, not only for agricultural purposes and fuel: The existence of several iron-smelting sites in the lateral valleys (Segard et al., 2003; Walsh and Mocci, 2003; Walsh et al., 2005) of the 'vallon d'Isola' could explain the urgent need of wood and heavier exploitations of the forests. All the tree and shrub taxa dropped to a minimum $(\mathrm{AP}<5 \%)$ and pollen indicators of grazing and pasture sharply increased, suggesting the presence of large flocks and cattle herds with an intensive pastoral exploitation in the valley, and probably beyond. Since the sixteenth century a new expansion of pine, fir and oak forests is regionally observed (PAZ LA9, 15-7.5 cm). The decrease of pastoral pollen indicators points to local grazing activity abandonment, even if the site remains largely open and above the tree line (NAP between 68 and $90 \%$, lack of woody plant macroremains).

\section{Aquatic and wetland plant macroremains data}

Figure 7 shows the succession of local plant communities and hydrological changes at Lauzons. MAZ I $(170.0-148.0 \mathrm{~cm})$ is correlated with the almost total absence of wetland plant macroremains in the sediment, indicating that the margins of the Lac des Lauzons were not colonized by plants. A first temporary increase in the water level associated with climatic improvement takes place at the beginning of the Holocene (MAZ II, 148.0-143.0 cm). Aquatic macrophytes dominated with Potamogeton filiformis which developed at this time. P. filiformis has the ability to spread rapidly in shallow water bodies with high $\mathrm{pH}$ and conductivity (Warner, 1990). The MAZ III (143.0-93.0 cm) associated with the Boreal and Atlantic periods, shows a shallowing of the lake and the development of rushes with Eleocharis sp., some Carex species, and then Menyanthes trifoliata. The presence of some macrophytes (Sparganium angustifolium, Potamogeton filiformis) indicates that at least seasonally stagnant water appeared at the site. The water level rises again at the beginning of the Sub-Boreal period (MAZ IV, 93.0-53.0 cm). Typically aquatic vegetation was dominated by Batrachium sp. and Sparganium angustifolium. Species of the Batrachium genus are known to be rapid colonizers in aquatic environments (Cohen, 2003). Hence, at that time swamp vegetation with Eleocharis sp. and Carex spp. declined. Gradual overgrowing of the lake is illustrated by the MAZ V (53.0-30.0 $\mathrm{cm})$ and VI (30.0-2.0 cm) which show spread of Juncus alpinus and J. filiformis. This process accelerated around 1900 cal. BP when aquatic species sharply declined with the ongoing terrestrialization of the lake. The terminal phase of the lake evolution is characterized by vegetation with Juncus filiformis, J. alpinus and Carex echinata as the most common species.

\section{Fungal spores}

Spores from various coprophilous fungi belonging to the Sordariales Order (Sordaria sp., Neurospora sp., Podospora sp., Zopfiella $\mathrm{sp}$.) have been lumped together. This group of fungi is linked to the presence of cattle and to grazing pressure (Buurman et al., 1995; Galop et al., 2003; Gauthier, 2001; López Sáez et al., 2002; van Geel and Aptroot, 2006; Van Geel et al., 1980, 2003). These spores appear in the Lauzons profile at about $100 \mathrm{~cm}$ depth (Figure 9), level dated to c. $6000 \mathrm{cal}$. BP and attributed to Ancient Neolithic. They present regular occurrences throughout the upper part of the sequence and reach really high values between 25 and $17.5 \mathrm{~cm}$ depth; this will be discussed below.

\section{Discussion}

\section{Comparison between Coleopteran succession and vegetation dynamics}

Comparison of beetle assemblage zones (BAZ), pollen assemblage zones (PAZ), and plant macrofossil assemblage zones (MAZ) shows some similarities between the three records, but also some clear discrepancies. Nevertheless, the similarity 
between these zonations suggests that they reflect major changes in the palaeoenvironments.

Lateglacial. There is an excellent agreement between the three records concerning the lowermost biozone. Beetle and plant remains are very rare in BAZ1 and MAZ I. This suggests that the oligotrophic lake occupied a rocky hollow left after the retreat of the ice cover, and was submitted to extremely harsh climatic conditions. Dominant pollen taxa include Ephedra, Artemisia and Chenopodiaceae, but the outstanding feature of this pollen chronozone is obviously the significant representation of Pinus sylvestris type, with almost 70\% of pollen representation at the basis of the sequence (Figure 5). This pollen is clearly of distant origin since insect data do not indicate any conifer-associated beetle in BAZ1 and reveal a totally bare environment around the lake. Such observation was already made in the same palaeoecological context at Lac Long Inférieur in Vallée des Merveilles (Ponel et al., 2001a, b). Isolated pollen occurrences of members of the association Quercetum mixtum correspond also to airborne pollen grains carried into the site by anabatic winds. Betula occurrences are certainly of local origin because isolated macroremains of Betula fruits have been identified at the end of the Lateglacial; Juniperus occurences suggest also that this tree was established locally because this taxon is a poor pollen disperser (Figure 5). The presence of birch individuals nearby probably accounts for the discovery of isolated specimens of forest margin Coleoptera (Anthophagus bicornis). The absence of the snow patch species Helophorus glacialis may be attributed to extremely cold conditions, too cold even for such a cryophilous species, but might also be linked to the purely rocky nature of the substratum. Based on biological markers and ${ }^{14} \mathrm{C}$ ages, a Lateglacial age is assigned to this biozone. It is likely that at such high altitudes, the warming of the Lateglacial interstadial is not recorded by plants and insects, therefore, we have not tried here to make any subdivision for this period (see for discussion Court-Picon, 2007).

Preboreal-early Boreal. The pollen curves of Cyperaceae and Juncaceae (Figure 9) show a sharp peak centred almost exactly on the Preboreal chronozone and on the early BAZ2, corresponding also to the appearance of Helophorus glacialis. The peak of aquatic macrophytes recorded in the first half of MAZ III suggest a rise of lake water level and a relative climatic improvement; it is also likely that rock weathering and accumulation of finegrained sediments by water streaming in and around the lake allowed both $H$. glacialis and Cyperaceae-Juncaceae to settle around the Lauzons lake. The striking increase of insect diversity in BAZ2 is obviously correlated with the simultaneous rise in the pollen curves of several tree species such as Betula, Pinus cembra, Corylus, Quercetum mixtum group, and more generally with the increase in plant diversity recorded during the Preboreal, and then the Boreal. The rise of Pinus cembra is not attested by occurrences of conifer-dependent insects that are totally missing in BAZ2. Therefore, it is certain that the pine was not established close to the site at that time. On the other hand, this period is also marked by a peak of forest margin Coleoptera matching exactly the massive occurrences of Betula macrofossils (Figures 4 and 5). At that time the treeline was certainly close to the Lac des Lauzons in the form of open birch woodland.

Atlantic-early Sub-Boreal. The start of repeated occurrences of conifer-dependent Coleoptera is clearly correlated with the rise of Abies pollen curve (Figure 5) although as proposed by
Court-Picon (2007), it is unlikely that the Abies forest established on the Lauzons shelf itself, a fact attested by the relatively low pollen percentages of this tree (15\%), the absence of Abies macrofossils, and the scarcity of conifer and forest Coleoptera. The reduction of tree and shrub diversity may explain the decrease of beetle diversity recorded at the transition BAZ2/ BAZ3. The temporary disappearance of Helophorus glacialis suggests a climatic improvement that could have induced the rise of the treeline of Abies. BAZ3 is also marked by a strong decrease (or even disappearance) in standing water Coleoptera. As indicated above, this well recorded event is difficult to explain. Furthermore, the pollen record does not provide any evidence for a drying up of the environment, although this period is clearly correlated with a climatic improvement. The aquatic and wetland plant macrofossils diagrams show that the beetle zone BAZ3 corresponds to two important botanical events: the sudden replacement of Eleocharis by Batrachium (transition between MAZ III and MAZ IV), and a slight but distinct temporary depression of the Sparganium angustifolium curve. Such changes could be attributed to a drying up of the lake allowing swamp species such as Eleocharis to bloom, followed by a rise of lake level causing a burst of Batrachium. The origin of these hydrological changes remains speculative: increasing regional climatic aridity, diminution of snow fall, landslide or perhaps a combination of all.

Middle Sub-Boreal. The rise in standing-water Coleoptera recorded at the end of BAZ3 and in BAZ4 is synchronous with a significant isolated peak of Batrachium macrofossils ( 86 fragments identified at $65 \mathrm{~cm}$ depth, Figure 7), a plant usually growing in relatively deep water. At the same time, there is a fall in almost all ecological categories of Coleoptera, whereas Helophorus glacialis reappears. This combination of entomological events in BAZ4 may be attributed to increased snow or rain fall, inducing increased erosion and activity of tributaries, accumulation of sediment in the lake, and rise of the lake level. Increased accumulation sediment inducing a decrease in plant and insect macrofossil content in a sedimentary sequence has already been described by AndrieuPonel et al. (2000). The hypothesis of increased snow fall is in agreement with the occurrence of Helophorus glacialis in BAZ4. This short period BAZ4 is equivalent with pollen zones LA5bLA6a (early Sub-Boreal). A climatic deterioration in this part of the pollen sequence is also evoked by Court-Picon (2007) to explain the beginning of the curve of Fagus (in LA5a), and later, that of Picea (in LA6a). There is therefore good agreement between the three palaeoecological markers.

Upper Sub-Boreal-early Sub-Atlantic. High numbers of Batrachium growing in deep water are again correlated with a good representation of standing-water Coleoptera, but both categories are strongly declining toward the top of these zones, suggesting a progressive infilling of the lake after a period of high water level and thriving of aquatic plants and beetles. Helophorus glacialis is still well represented, indicating open environment. Pollen data suggest a rise in human activities, with cultivation and pastoral practices around the lake. Such events are not clearly documented in the beetle sequence since the coprophilous Coleoptera are declining in BAZ5, although the decline of other categories such as forest margin Coleoptera and the almost complete extinction of beetles associated with trees is perhaps a consequence of human impact. Unfortunately, no beetle associated with ruderals are recorded in this part of the sequence. 
Sub-Atlantic. The extinction of almost all ecological categories of beetles (and aquatic plants) is certainly a consequence of the progressive infilling of the lake; in such conditions, insect remains are not rapidly buried into lacustrine sediments. Instead, they are retained in open air by the dense vegetation growing on the infilled peat bog, and are then rapidly destroyed after death by microorganism activities and oxidation processes. The beetle assemblages extracted from peaty sediments deposited under aerobic conditions are usually extremely poor, and consists of corroded fragments. It is tempting to attribute the rise of sedimentation rate to increased erosion, triggered by a rise of human activities around the lake, especially forest clearing and pastoralism which were intense at that time according to pollen data (Court-Picon, 2007). However, the lithology of the core shows that the sediment corresponding to BAZ6/MAZ VI/SubAtlantic is predominantly made of peat and organic gyttja, which suggests that the infilling of the lake was a consequence of a natural transformation of the lake into a peat bog, maybe under a drier climate. Other proxies such as pollen and plant macroremains are much better preserved; the beetle zone BAZ6 corresponds to massive occurrences of Juncus seeds, Poaceae, Cyperaceae and Juncaceae pollen, and also coprophilous fungal spores. The marked peak of the latter suggests a particular abundance of domestic animals on the site in the uppermost part of the record, which is in agreement with archaeological data, but not with the beetle record. Here, we try to explain this disagreement between insect and spore records.

\section{Coprophilous Coleoptera versus coprophilous fungi}

Comparison of frequencies of coprophilous Coleoptera and percentages of coprophilous fungi is striking (Figure 9) and show a complete discrepancy: Dung beetles are present and even abundant in beetle zones BAZ2, BAZ3, BAZ4 and BAZ5, but very rare, scattered in the form of isolated specimens in BAZ6, which is conversely marked by significant occurrences of coprophilous fungal spores. The apparent inconsistency of both records needs to be clarified because both fungal spores and dung beetles have often been used as markers of pastoralism (Buurman et al., 1995; Galop et al., 2003; Gauthier, 2001; López Sáez et al., 2002; van Geel and Aptroot, 2006; Van Geel et al., 1980, 2003).

Our interpretation of this tricky record of coprophilous proxies may be summarized as follows. During the phase of lacustrine sedimentation, dung beetles associated with large domestic or wild mammals grazing around the lake fly during warm periods, occasionally fall in the lake and are then trapped on the water surface, as frequently observed today especially in mountains (Ponel, personal observations in the field). Unable to escape from the water, the beetles die and sink to the bottom of the lake where they are buried in the fine sediments. At the same time, fungal spores (if any) are produced on solid ground around the site and cannot be transported into the lake, with the exception of isolated spores carried by wind and small ephemeral streams into the lake, where they accumulate at the margins but are not incorporated into the lacustrine sediments.

During the phase of peat accumulation when the lake has almost totally infilled and become a peat bog, domestic as well as wild animals are able to graze around or even over the peat itself, but beetles are filtered and retained by the dense fibrous network of hygrophilous vegetation that forms the peat bog. Consequently, the insects either manage to escape from the site, or die on firm ground. Hence, they cannot be rapidly buried and preserved in the peaty depositional environment and are then submitted to degradation by oxidation or bacterial and microorganism attacks, along with the other Coleoptera remains. The degradation of insect fragment assemblages in such adverse taphonomic conditions is frequently observed in the uppermost part of many sedimentary records, in which the scarce remaining fragments have a corroded and rusty aspect (personal observations). At the same time, the dung deposited on the peat is colonized by fungi, and their spores are easily preserved in the interstices of the peat deposit because of their smaller size.

Therefore, we suggest here that both proxies should be used with caution when considered separately, since the present study shows clearly that fungal spores have recorded the presence of big animals only in the final stage of the formation of the studied sedimentary profile, when the lake was almost totally infilled and converted into a peat bog, whereas the dung beetle record was reliable only during lacustrine stages. It is important, however, to remember that dung beetles are not exclusively associated with domestic mammals and that the continuous occurrence of this category of insects in the sequence of Lauzons does not imply necessarily that cattle associated with pastoralism were present throughout but may also indicate the quasi-permanent presence of wildlife in the area. Such difficulties in the interpretation of dung beetle proportions in fossil Coleopteran assemblages has been recently underlined by Smith et al. (2010).

\section{Where was the treeline?}

The treeline is one of the most difficult 'palaeo-ecotones' to reconstruct from pollen data only, as illustrated by the pollen diagram from Lauzons. It raises the question of the relevance of past landscapes reconstruction in high-altitude sites. For example, although Pinus pollen dominates during most of the record, no pine seed or needle was found in the sequence, suggesting that pine never massively invaded the area. Kullman (1991), Ponel et al. (2001a, b), Ortu (2002), Court-Picon et al. (2005, 2006), Court-Picon (2007) and others demonstrated that long-distance pollen is often overrepresented in unforested highlands. A recent review performed by Müller et al. (2006), including the pollen diagram from Lauzons, proposed that during the postglacial, scattered populations of Pinus cembra have developed in the close vicinity of the lake within local formations of Betula and Alnus alnobetula. If we accept this hypothesis, the total absence of any macroremains of Pinus cembra (and Pinus sylvestris) requires explanation. Finally, the potential presence of conifers close to the lake can only be established on the basis of occurrences of conifer-dependent insect subfossils. It can be assumed that isolated stands of Pinus have lived in the area but the high abundance of open-ground/highaltitude Coleoptera (especially Aphodius mixtus) and the regular presence of the cold-adapted Helophorus glacialis suggest that the landscape was dominated by mixed grasslands/shrublands.

The site of Lauzons was probably close to the treeline at some times but remained unforested throughout the Holocene. This absence of forest around the site has undoubtedly a local explanation. Indeed, elsewhere in the French Alps, and at similar altitudes, the presence of Pinus cembra forests has been evident during the Holocene at c. 6500 cal. BP (Müller et al., 2006; Talon, 2010). It is interesting to note that Finsinger and Tinner (2007) at Lac Supérieur de Fully in the Swiss Alps have provided evidence of an important delay in the expansion of the conifer forest at the same altitude (2135 $\mathrm{m}$ a.s.1.): 
Timberline trees such as Pinus cembra and Larix are recorded after 8200 cal. BP around the Fully lake, whereas higher elevations were reached elsewhere in the region as soon as 11000 cal. BP. This delay is attributed to climatic factors, but also to more local geomorphological conditions.

Strikingly, in the Lauzons palaeoecological record, Larix is under-represented in the pollen record and absent in the plant macrofossil record, although its presence has been documented in the Queyras massif (southern Alps) at $2000 \mathrm{~m}$ a.s.l. at about 6000 cal. BP (Touflan and Talon, 2008). Lastly, imprints of Pinus uncinata were discovered in the early-Holocene travertine formations located at $2200 \mathrm{~m}$ a.s.l. (Ali et al., 2003). Queyras belongs to the internal Alps in terms of biogeography (Ozenda, 1985), where insolation and dryness are optimal for larches, contrary to Lauzons, located westward in a transition zone to the external Alps. This difference could explain the late arrival of this tree, nowadays present in the valley because of human activity.

\section{Causes of this long-lasting non-forested landscape: Climate, edaphic conditions, human impact?}

In the pollen diagram, there is no evidence for drastic past climate change, except for the Lateglacial phases. These Lateglacial climate fluctuations identified at Lauzons are clearly similar to those observed elsewhere in the subalpine domain in the region. The absence of local woodstands during the Bølling/Allerød interstadial is not surprising according to David (1993) who has shown that in the Maurienne massif the timberline was below the altitude of the study site in this part in the Alps. On the contrary, several pedoanthracological studies have shown that the treeline could reach the altitude of Lauzons during the Holocene (Talon et al., 1998; Touflan and Talon, 2008). In the Central Swiss Alps, pollen and plant macrofossil studies also suggest a high treeline (Larix decidua and Pinus cembra) during the Lateglacial reaching the altitude of $2200 \mathrm{~m}$ at the very beginning of the Holocene (Kaltenrieder et al., 2005). Here, it remains difficult to interpret the pollen record since the high altitude of the site leads to the overrepresentation of regional pollen input that blurs the local pollen signal. However, the plant macrofossil record clearly demonstrates that, except during the Boreal and a short phase during the Atlantic period, where Betula was locally present, the forest limit did not reach the Lauzons lake. The insect record also expresses the same evidence. The geomorphological context and the topography of the site might explain why no dense forests have developed in the area: The lake is located on a shelf surrounded by very steep slopes, just underneath the remnants of a rock glacier. The southern part of the lake is bordered by abrupt rocky cliffs that could have been a natural barrier. Obviously, such physiographic context is not an impassable obstacle for Pinus cembra or Pinus sylvestris (which are both pioneer trees) but this could have slowed down the postglacial forest dynamics. It is also possible that during the earliest phases of the Holocene the rock glacier was still active, generating instability of the catchment area and severe erosional phases. This hypothesis is speculative since no geomorphological investigation has been carried out yet. The edaphic conditions might also have been unfavourable to any forest development. In some circumstances, the nature of the substratum in the slope is decisive for tree growth (Bélingard et al., 1998). Geomorphological particularities are also evoked by Finsinger and Tinner (2007) to explain the delay in the Holocene expansion of conifer forest at lake Fully in Switzerland.

\section{Comparison with other beetle records from the Alps}

The beetle sequence associated with plant macrofossil and pollen data analysed at $2100 \mathrm{~m}$ in the Taillefer Massif, French Alps (Ponel et al., 1992; Tessier et al., 1993), provides a different scenario. After a Lateglacial- early Holocene phase marked by the dominance of a pioneer cold-adapted fauna suggesting a periglacial steppic landscape, a conifer forest became quickly established just after $c$. $8400 \mathrm{cal}$. BP. The discovery of many Pinus uncinata trunks buried into peat bogs scattered throughout the plateau confirms this hypothesis. Many saproxylophagous and forest-associated beetles suggest that this forest was made of large old trees: The occurrence of the stag beetle Ceruchus chrysomeli$n u s$ is especially informative since this stenotopic lucanid lives during its larval and adult stages in rotten tree stumps and trunks, in cold and wet large forests (Paulian, 1959). This beetle is a poor flier, and does not wander readily outside its habitat, so its occurrence on the Taillefer plateau cannot be attributed to upward transport by wind. However, open glades persisted throughout the Holocene, and prior to human activity the forest limit on the plateau was apparently a zone of competition between forest and grassland. Later in the sequence, beetle data suggest that the forest declined gradually, under the influence of a combined action of climate cooling and human activities such as pastoralism.

In Vallée des Merveilles, Alpes-Maritimes, France (Ponel et al., 2001a, b), almost at the same altitude to Lauzons (2090 m), the insect record suggests clearly a rise of the treeline during the Holocene, indicated first by a temporary rise in the category of beetles associated with forest margins, which reaches a maximum at the end of the Boreal. During the Atlantic this category declines to the benefit of forest insects. This development corresponds obviously to an elevation of the treeline during the Atlantic and the Sub-Boreal, and to an apparent increase in the density of the forest cover. Coleoptera dependent on Abies and Larix appear at that time. The last event occurs at the end of the Sub-Boreal and in the Sub-Atlantic: It is characterised by a regular decrease of tree-dependent taxa, attributed to human actions such as forest clearance associated with pastoralism. Contrary to Taillefer, there is no indication from the cold-adapted beetle record that a cooling of the climate may account for this forest demise. However, compared with Taillefer, the insect assemblages from Lac Long Inférieur do not provide the same picture of the forest cover, since stenotopic beetles associated with old, wet and dense forests such as Ceruchus chrysomelinus are not recorded. It is likely that the forest cover around Lac Long Inférieur at its peak period (Atlanticearly Sub-Boreal) was more analogous to scattered individuals forming a light woodland established on grassland, comparable with a modern Larix forest.

\section{Conclusions}

The main conclusions that can be drawn from the analysis of this beetle sequence is the relative stability of the palaeoenvironment, at least in the vicinity of the Lauzons lake. The most significant feature in the beetle record is the regular occurrences in significant numbers of Aphodius mixtus throughout the sequence. By comparison with other insect successions from the Alps (Ponel, 1997; Ponel et al., 1992, 1999, 2001a, b), such persistence of Aphodius mixtus associated with open-ground/high-altitude Coleoptera including the snow patch species Helophorus glacialis suggests that the environment remained in the form of alpine 
grasslands throughout the sequence. However, it is likely that a shrubby vegetation was constantly present in the form of a willow, alder or birch fringe around the lake, in marshy areas. This interpretation is supported by the continuous curve of one of the more frequent taxa in the sequence, i.e. Luperus cf. viridipennis, which spans the whole sequence from BAZ2 to BAZ6. This leaf beetle is associated with willows and birches and is today especially abundant in this region on small trees and bushes at the upper limit of the treeline. No forest cover could establish on the Lauzons shelf itself, but repeated occurrences of isolated specimens of Coleoptera associated with conifer and deciduous trees give a hint that trees were present nearby, certainly on the steep slopes below the lake. Regular occurrences of Helophorus glacialis also suggest that climatic conditions were cool enough to eliminate the forest from the shelf and close to the temperature threshold for this cold adapted insect $\left(T_{\max }\right.$ close to $\left.10^{\circ} \mathrm{C}\right)$. The final drastic impoverishment of the beetle assemblages should be attributed to adverse taphonomic conditions linked to the infilling of the lake although the impact of grazing and other perturbations from human origin cannot be ruled out.

The total absence throughout the sequence of running-water taxa such as Elmidae is also striking. It suggests that at no time a stream or torrent was flowing into the site, although water seeping occurred probably on the steep shores of the lake, especially from below the rocky glacier. In such hydrological conditions, it is likely that very few allochthonous insects were transported by water streaming. This is especially important for the interpretation of beetle assemblages, because in such conditions coldadapted taxa from higher and colder locations cannot be carried into the site, which could blur the climatic record.

Undoubtedly, the site of Lauzons has been under 'anthropic influence': Relicts of sheep folds and shepherd shelters were found close to the lake. These archaeological structures indicate that man occupied continuously the sites since $c .3728$ cal. BP (early Bronze Age) until modern time (Palet Martinez, 2000; Palet Martinez et al., 2003). At this period, both NAP and 'anthropogenic' pollen curves start increasing (PAZ 6b), and may suggest that the late-Holocene opening of the site is of human origin, however such hypothesis cannot be proposed for the early-Holocene period, before the Bronze Age. As indicated by Court-Picon (2007) and Mocci et al. (2008), earlier pollen markers of anthropisation (pastoral activities and very local forest clearings) are recorded between 6000 and 4500 BC, however these indices are so subtle that they cannot be attributed to local human action at the altitude of Lac des Lauzons. We must thus accept the idea that the forest limit does not follow a horizontal continuous limit governed by the unique regional climate, but depends on several other local parameters. Application of some other palaeoecological methods such as pedoanthracology could help in the future to reveal further information concerning this problem.

\section{Acknowledgements}

G.R. Coope and J. Coulon provided much help and advice. The identification of Phloeostichus denticollis was made possible by H. Brustel who provided a voucher specimen of this rare species. Thanks also go to the anonymous reviewers for helpful comments and improvement of the English. This research was funded by the CNRS program PEVS Environnement, Vie et Sociétés 'Forêts et Troupeaux dans les Alpes françaises du Sud du Tardiglaciaire à l'époque actuelle'.

\section{References}

Ali A, Carcaillet C, Guendon J-L, Quinif Y, Roiron P and Terral J-F (2003) The early Holocene treeline in the southern French Alps: New evidence from travertine formations. Global Ecology and Biogeography 12: 411-419.

Andrade Olalla A, Valdeolmillos A and Zapata Ruiz B (1994) Modern pollen spectra and contemporary vegetation in the Paramera mountain range (Avila, Spain). Review of Palaeobotany and Palynology 82: 127-139.

Andrieu V, de Beaulieu J-L, Ponel P and Reille M (1997) Les distorsions de l'enregistrement pollinique de l'histoire de la végétation du dernier cycle climatique: Exemples de séquences lacustres du sud de la France. Geobios 21: 195-202.

Andrieu-Ponel V, Ponel P, Bruneton H and Leveau P (2000) Palaeoenvironments and cultural landscape of the last 2000 years reconstructed from pollen and coleopteran records in the Lower Rhône Valley, southern France. The Holocene 10: 341-355.

Angus R (1992) Insecta Coleoptera Hydrophilidae Helophorinae, Süßwasserfauna von Mitteleuropa 20/10-2. Stuttgart: Gustav Fischer Verlag.

Balachowsky AS (1949) Coléoptères Scolytidae. Faune de France 50. Paris: Librairie de la Faculté des Sciences.

Bélingard C, Tessier L and Edouard J-L (1998) Reboisement et dynamique naturelle dans les forêts sub-alpines (Haut-Verdon, Alpes du Sud, France). Géographie Physique et Quaternaire 52: 1-10.

Berland L (1935) Premiers résultats de mes recherches en avion sur la faune et la flore atmosphérique. Annales de la Société Entomologique de France CIV 73: 73-97.

Blaauw M (2010) Methods and code for 'classical' age-modelling of radiocarbon sequences. Quaternary Geochronology 5(5): 512-518.

Blunier T, Chappellaz J, Schwander J, Stauffer B and Raynaud D (1995) Variations in atmospheric methane concentration during the Holocene epoch. Nature 374: 46-49.

Brugiapaglia E, de Beaulieu J-L, Guiot J and Reille M (1998) Transect de pluie pollinique et étagement de la végétation dans le massif du Taillefer (Isère, France). Géographie physique et Quaternaire 52: 209-218.

Buurman J, van Geel B and van Reenen GBA (1995) Palaeoecological investigations of a late Bronze Age watering-place at Bovenkarspel, the Netherlands. In: Herngreen GFW and van der Valk (eds) Neogene and Quaternary Geology of North-West Europe. Mededelingen Rijks Geologische Dienst, 52: 249-270.

Caillol H (1913) Catalogue des Coléoptères de Provence 2. Marseille: Société linnéenne de Provence.

Caseldine C and Pardoe H (1994) Surface pollen from alpine/sub-alpine southern Norway: Applications to Holocene data. Review of Palaeobotany and Palynology 82: 1-15.

Cohen AS (2003) Paleolimnology. The History and Evolution of Lake Systems. Oxford University Press.

Coope GR (1986) Coleoptera analysis. In: Berglund BE (ed.) Handbook of Holocene Palaeoecology and Palaeohydrology. Chichester: Wiley \& Sons, 703-713.

Coope GR (1998) Insects. In: Preece RC and Bridgland DR (eds) Late Quaternary Environment Change in North-west Europe: Excavations at Holywell Coombe, South-east England. London: Chapman \& Hall, 213-233.

Coulon J, Marchal P, Pupier R, Richoux P, Allemand R, Genest L-C et al. (2000) Coléoptères de Rhône-Alpes. Carabiques et Cicindèles. Muséum d'Histoire naturelle de Lyon, Société linnéenne de Lyon.

Court-Picon M (2007) Mise en place du paysage dans un milieu de moyenne et haute montagne du tardiglaciaire à l'époque actuelle. Thèse de Doctorat, Université de Franche-Comté, Besançon, France.

Court-Picon M, Buttler A and de Beaulieu J-L (2005) Modern pollen-vegetation relationships in Champsaur valley (French Alps) and their potential in the interpretation of fossil pollen records of past cultural landscapes. Review of Palaeobotany and Palynology 135: 15-39. 
Court-Picon M, Buttler A and de Beaulieu J-L (2006) Modern pollen/vegetation/land-use relationships in mountain environments: An exemple from the Champsaur valley (French Alps). Vegetation History and Archaeobotany 15: 151-168.

David F (1993) Évolution de la limite supérieure des arbres dans les Alpes françaises du Nord depuis la fin des temps glaciaires. Thesis, Université d'Aix-Marseille III.

David F and Barbero M (1995) De l'histoire du genre Betula dans les Alpes françaises du Nord. Review of Palaeobotany and Palynology 89: 445-467.

de Beaulieu JL (1977) Contribution pollenanalytique à l'histoire tardiglaciaire et holocène de la végétation des Alpes méridionales françaises. Thèse de Doctorat, Université d'Aix-Marseille III, France.

Debelmas J (1982) Alpes du Dauphiné. Guides géologiques régionaux, Paris: Masson.

Drotz M (1997) Genetical and morphological variation in the diving beetle Agabus bipustulatus (Coleoptera: Dytiscidae) along an altitudinal gradient across north Sweden. Degree Thesis in Biology, University of Umeå.

Español Coll F (1992) Coleoptera Anobiidae. Fauna Ibérica 2. Madrid: Museo Nacional de Ciencias Naturales, CSIC.

Faegri K and Iversen J (1975) Textbook of Pollen Analysis. New York: Hafner Press.

Finsinger W and Tinner W (2007) Pollen and plant macrofossils at Lac de Fully (2135 m a.s.1.): Holocene forest dynamics on a highland plateau in the Valais, Switzerland. The Holocene 17: 1119-1127.

Frits Th, Spieksma M, Nikkels BH and Bottema S (1994) Relationship between recent pollen deposition and airborne pollen concentration. Review of Palaeobotany and Palynology 82: 141-145.

Gaillard MJ and Lemdahl G (1994) Lateglacial insect assemblages from Grand-Marais, south-western Switzerland - Climatic implications and comparison with pollen and plant macrofossil data. Dissertationes Botanicae 234: 287-308.

Galop D, Mazier F, Lopez-Saez J-A and Vannière B (2003) Palynologie et histoire des activités humaines en milieu montagnard. Bilan provisoire des recherches et nouvelles orientations méthodologiques sur le versant nord des Pyrénées. Archéologie du Médiéval 21: 159-170.

Gauthier E (2001) Evolution de l'impact de l'homme sur la végétation du massif jurassien au cours des quatre derniers millénaires. Nouvelles données palynologiques. Thèse de Doctorat, Université de Franche-Comté, Besançon, France.

Gobert J, Ozenda P and Tonnel A (1966) Carte de la végétation de la France au 1/200 000. feuille 60, Gap. Toulouse: CNRS.

Goeury C (1988) Acquisition, gestion et représentation des données de l'analyse pollinique sur micro-ordinateur. Institut français de Pondichéry, Travaux Section Sciences et Techniques 25: 405-416.

Goeury C and de Beaulieu J-L (1979) À propos de la concentration du pollen à l'aide de la liqueur de Thoulet dans les sédiments minéraux. Pollen et spores 21: 239-252.

Hansen M (1987) The Hydrophiloidea (Coleoptera) of Fennoscandia and Denmark. Fauna Entomologica Scandinavica 18, Brill, Leiden-Copenhagen: Scandinavian Science Press.

Hoffmann A (1954) Coléoptères Curculionides 2, Faune de France 59. Paris: Librairie de la Faculté des Sciences.

Hoffmann A (1958) Coléoptères Curculionides 3, Faune de France 62. Paris: Librairie de la Faculté des Sciences.

Holmen M (1987) The Aquatic Adephaga (Coleoptera) of Fennoscandia and Denmark. I. Gyrinidae, Haliplidae, Hygrobiidae and Noteridae. Fauna Entomologica Scandinavica 20, Brill, Leiden-Copenhagen: Scandinavian Science Press.

Jackson DJ (1973) The influence of flight capacity on the distribution of aquatic Coleoptera in Fife and Kinross-shire. Entomologist's Gazette 24: $247-293$.
Jeannel R (1941) Coléoptères Carabiques 1. Faune de France 39. Paris: Librairie de la Faculté des Sciences.

Jeannel R (1942) Coléoptères Carabiques 2. Faune de France 40. Paris: Librairie de la Faculté des Sciences.

Juggins S (2003) C $C^{2}$ User Guide. Software for Ecological and Palaeoecological Data Analysis and Visualisation. University of Newcastle.

Kaltenrieder P, Tinner W and Ammann B (2005) Long-term vegetation history at timberline in the Swiss Alps (Alpe d'Essertse, VS). Botanica Helvetica 115: $137-154$.

Koch K (1989a) Die Käfer Mitteleuropas, Ökologie 1. Krefeld: Goecke and Evers.

Koch K (1989b) Die Käfer Mitteleuropas, Ökologie 2. Krefeld: Goecke and Evers.

Koch K (1992) Die Käfer Mitteleuropas, Ökologie 3. Krefeld: Goecke and Evers.

Kullman L (1991) Pattern and process of present tree limit in the Tärna region, southern Swedish Lapland. Fennia 169: 25-38.

Lemdahl G (2000) Lateglacial and early Holocene insect assemblages from sites at different altitudes in the Swiss Alps - Implications on climate and environment. Palaeogeography, Palaeoclimatology, Palaeoecology 159: 293-312.

Lindroth CH (1985) The Carabidae (Coleoptera) of Fennoscandia and Denmark. Fauna Entomologica Scandinavica 15 (part 1), Brill, LeidenCopenhagen: Scandinavian Science Press.

Lindroth CH (1986) The Carabidae (Coleoptera) of Fennoscandia and Denmark. Fauna Entomologica Scandinavica 15 (part 2), Brill, LeidenCopenhagen: Scandinavian Science Press.

Lindroth CH (1992) Ground Beetles of Fennoscandia 1, Specific Knowledge Regarding the Species. Andover: Intercept.

López Sáez JA, Lopez Garcia P and Martin Sanchez M (2002) Palaeoecology and Holocene environmental change from a saline lake in south-west Spain: Protohistorical and prehistorical vegetation in Cadiz Bay. Quaternary International 93-94: 197-206.

Lucht WH (1987) Die Käfer Mitteleuropas, Katalog. Krefeld: Goecke and Evers.

Lumaret J-P (1990) Atlas des Coléoptères Scarabéides Laparosticti de France. Paris: Muséum National d'Histoire Naturelle, Secrétariat de la Faune et de la Flore.

Lumaret J-P and Stiernet N (1990) Inventaire et distribution des Scarabéides coprophages dans le Massif de la Vanoise. Travaux Scientifiques du Parc National de la Vanoise 17: 193-228.

Lumaret J-P, Lobo JM and Jay-Robert P (1996) Catalogue et atlas des Scarabéides Laparosticti endémiques de France. Collection Patrimoines Naturels 26, Paris: Service du Patrimoine Naturel/IEGB/MNHN-OPIE.

Mocci F, Walsh K, Richer S, Court-Picon M, Talon B, Tzortzis S et al. (2008) Archaeology and Palaeoenvironment in the Southern French Alps: the Late Neolithic to the Roman Period in the Argentièrois, Champsaur and Ubaye High Altitude Massifs. Collection EDYTEM no. 6, Le Bourget-duLac: Cahiers de Paléoenvironnement.

Müller SD, Nakagawa T, de Beaulieu J-L, Court-Picon M, Fauquette S and Genries A (2006) Paléostructures de végétation à la limite supérieure des forêts dans les Alpes françaises internes. Comptes Rendus Biologie 329: 502-511.

Nilsson AN and Holmen M (1995) The Aquatic Adephaga (Coleoptera) of Fennoscandia and Denmark, II. Dytiscidae. Fauna Entomologica Scandinavica 32, Brill, Leiden-Copenhagen: Scandinavian Science Press.

Ortu E (2002) Reconstruction sur base pollinique de la dynamique de la végétation tardiglaciaire et holocène dans les Alpes maritimes italiennes. Thèse de Doctorat, Université d'Aix-Marseille III, France.

Ozenda P (1985) La végétation de la chaîne alpine dans l'espace montagnard européen. Paris: Masson. 
Palet Martinez J-M (2000) Sondages archéologiques sur les structures pastorales des sites Pré Brunet, Lac de Lauzons et Cabanes de Rougnous. Aix-en-Provence: CNRS, Centre Camille Jullian, Parc National des Écrins.

Palet Martinez J-M, Ricou F and Segard M (2003) Prospections et sondages sur les sites d'altitude en Champsaur (Alpes du sud). Archéologie du Midi Médiéval 21: 199-210.

Paulian R (1959) Coléoptères Scarabéidés. Faune de France 63. Paris: Office Central de Faunistique, Lechevalier.

Paulian R and Baraud J (1982) Lucanoidea et Scarabaeoidea. Faune des Coléoptères de France 2, Encyclopédie Entomologique XLIII, Paris: Lechevalier.

Pfeffer A (1995) Zentral- und westpaläarktische Borken- und Kernkäfer. Pro Entomologia, c/o Naturhistorisches Museum Basel.

Ponel P (1997) Late Pleistocene Coleopteran fossil assemblages in high altitude sites: A case study from Prato Spilla (northern Apennines, Italy). In: Studies in Quaternary Entomology - An Inordinate Fondness for Insects. London: Quaternary Research Association/Wiley, Quaternary Proceedings 5, 207-218.

Ponel P and Richoux P (1997) Difficultés d'interprétation des assemblages de Coléoptères fossiles quaternaires en milieu d'altitude. Geobios 21: 213-219.

Ponel P, de Beaulieu J-L and Tobolski K (1992) Holocene palaeoenvironments at the timberline in the Taillefer Massif, French Alps: A study of pollen, plant macrofossils and fossil insects. The Holocene 2: 117-130.

Ponel P, Jay P and Lumaret J-P (1995) Past and present changes in the coleopteran fauna since the end of the last glaciation: the case of the Western Alps and the Apennines. In: Guisan A, Holten JI, Spichiger R and Tessier L (eds) Potential Ecological Impacts of Climate Change in the Alps and Fennoscandian Mountains. Genève: Editions des Conservatoire et Jardin botaniques, 159-172.

Ponel P, Coope GR, Andrieu-Ponel V and Reille M (1999) Coleopteran evidence for a mosaic of environments at high altitude in the eastern Pyrénées, France, during the climatic transition between the Allerod and Younger Dryas. Journal of Quaternary Science 14: 169-174.

Ponel P, Andrieu-Ponel V, Parchoux F, Juhasz I and de Beaulieu J-L (2001a) Late-glacial and Holocene high-altitude environmental changes in Vallée des Merveilles (Alpes-Maritimes, France): Insect evidence. Journal of Quaternary Science 16: 795-812.

Ponel P, Parchoux F, Andrieu-Ponel V and Juhasz I (2001b) A LateglacialHolocene fossil insect succession from Vallée des Merveilles (Lac Long Inférieur, French Alps) and its palaeoecological implications. Arctic, Antarctic and Alpine Research 33: 481-484.

R Development Core Team (2010) R: A Language and Environment for Statistical Computing. Vienna: R Foundation for Statistical Computing, ISBN 3-900051-07-0. http://www.R-project.org (last accessed 01 February 2010).

Rose O and Callot H (2007) Redécouverte de Phloeostichus denticollis Redtenbacher, 1842 dans le massif des Vosges (France) (Coleoptera Phloeostichidae). L'Entomologiste 63: 129-133.
Ruffaldi P (1994) Relationship between recent pollen spectra and current vegetation around the Cerin peat bog (Ain, France). Review of Palaeobotany and Palynology 82: 97-112.

Sainte-Claire Deville J (1935-1938) Catalogue raisonné des Coléoptères de France. L'Abeille 36, 1-467.

Segard M, Walsh K and Court-Picon M (2003) L'occupation de la haute montagne dans les Alpes occidentales. Apport de l'archéologie et des analyses paléoenvironnementales. In: Boëtsch G, Devriendt W and Piguel A (eds) Permanence et changements dans les sociétés alpines. Actes du Colloque de Gap, 2002, Aix-en-Provence: Edisud, 17-30.

Smith D, Whitehouse N, Bunting MJ and Chapman H (2010) Can we characterise 'openness' in the Holocene palaeoenvironmental record? Modern analogue studies of insect faunas and pollen spectra from Dunham Massey deer park and Epping Forest, England. The Holocene 20: 215-229.

Talon B (2010) Reconstruction of Holocene high-altitude vegetation cover in the French southern Alps: Evidence from soil charcoal. The Holocene 20: 35-44.

Talon B, Carcaillet C and Thinon M (1998) Étude pédoanthracologique des variations de la limite supérieure des arbres au cours de l'Holocène dans les Alpes françaises. Géographie physique et Quaternaire 52: 1-14.

Tessier L, de Beaulieu J-L, Coûteaux M, Edouard J-L, Ponel P, Rolando C et al. (1993) Holocene palaeoenvironments at the timberline in the French Alps - A multidisciplinary approach. Boreas 22: 244-254.

Touflan P and Talon B (2008) Histoire et dynamique d'une forêt subalpine (Alpes du sud, Queyras) en vue de la reconstitution des paysages du passé. In: Galop D (ed.) Paysages et Environnement. De la reconstitution du passé aux modèles prospectifs. Annales littéraires; Série 'Environnement, sociétés et archéologie', Besançon: Presses universitaires de FrancheComté, 171-184.

Van Geel B and Aptroot A (2006) Fossil ascomycetes in Quaternary deposits. Nova Hedwigia 82: 313-329.

Van Geel B, Bohncke SJP and Dee H (1980) A palaeoceological study of an upper Late Glacial and Holocene sequence from 'De Borchert', The Netherlands. Review of Palaeobotany and Palynology 31: 367-392, 397-448.

Van Geel B, Buurman J, Brinkkemper O, Schelvis I, Aptroot A, van Reenen G et al. (2003) Environmental reconstruction of a Roman period settlement site in Uitgeest (The Netherlands), with special reference to coprophilous fungi. Journal of Archaeological Science 30 873-883.

Vienna P (1980) Coleoptera Histeridae. Fauna d'Italia 16. Bologna: Calderini.

Walsh K and Mocci F (2003) 9000 ans d'occupation du sol en moyenne et haute montagne: La vallée de Freissinières dans le Parc national des Ecrins. Archéologie du Midi Médiéval 21: 185-198.

Walsh K, Mocci F, Court-Picon M, Tzortzis S, Palet-Martinez J-M, Dumas V et al. (2005) Dynamique du peuplement et activités agropastorales durant l'Âge du Bronze dans les massifs du haut Champsaur et de l'Argentiérois (Hautes-Alpes). Documents d'Archéologie Méridionale 28: 5-44.

Warner BG (1990) Plant macrofossils. In: Warner BG (ed.) Methods in Quaternary Ecology. Geoscience Canada, Reprint Series 5, St. John's: Geological Association of Canada, 53-64.

Zanetti A (1987) Coleoptera Omaliinae. Fauna d'Italia 25. Bologna: Calderini. 